University of Miami Law School University of Miami School of Law Institutional Repository

1995

\title{
Breaking the Cycle of Despair: Street Children in Guatemala City
}

Tamara Rice Lave

University of Miami School of Law, tlave@law.miami.edu

Follow this and additional works at: https://repository.law.miami.edu/fac_articles

Part of the Human Rights Law Commons

\section{Recommended Citation}

Tamara Rice Lave, Breaking the Cycle of Despair: Street Children in Guatemala City, 27 Colum. Hum. Rts. L. Rev. 57 (1995).

This Article is brought to you for free and open access by the Faculty and Deans at University of Miami School of Law Institutional Repository. It has been accepted for inclusion in Articles by an authorized administrator of University of Miami School of Law Institutional Repository. For more information, please contact library@law.miami.edu. 


\title{
Breaking the Cycle of Despair: Street Children in Guatemala City
}

\author{
by Tamara Rice Lave*
}

On March 4, 1990, a group of children sat inhaling glue from plastic bags near the Klee Pharmacy in Zone 1 of Guatemala City. It was late, and they were cold and hungry. Street children who either had no families or had left them to escape abuse, they used the glue to dull their physical and emotional pain.

Sometime after midnight, five uniformed police officers approached the children. Four of them yelled insults and poured glue into the children's hair. The only one who protested, Nahaman Carmona Lopez, was kicked into a state of unconsciousness by the four policemen. He died in the hospital eleven days later. Nahaman was only thirteen years old."

Though extreme, Nahaman's case is not uncommon. Most street children flee abuses of the home only to confront cruelty on the street. ${ }^{1}$ With no adult role models, they group together, often stealing to buy food and sniffing glue to comfort themselves. ${ }^{2}$ The problem is serious enough to attract the attention of both the national and

* B.A., Haverford College (1990); J.D., Stanford Law School (1995). I would like to thank John Barton, Terry Karl, Kathleen Morrison, Sophie Pirie, and Jane Depledge for their insightful comments and criticism. I would also like to thank Bruce Harris and everyone else at Casa Alianza, without whom I would not have been exposed to street children and their problems. This Article was made possible by the generous support of the Latin American Studies Center at Stanford University and the Mellon Foundation.

** Casa Alianza, the Latin American branch of Covenant House, has been aggressive in fighting for the rights of street children. In 1990, Casa Alianza initiated proceedings against Nahaman's killers. In 1992, after legal obstacles, delayed proceedings, overturned decisions, and death threats, Casa Alianza won a landmark case. The four policemen were fined 5000 quetzals each (about U.S. $\$ 1000$ ) and sent to jail for twelve years. It was the second time in Guatemala's history that police were convicted of committing human rights abuses. See Casa Alianza, 1991 Annual Report (Abuses Against the Street Children of Guatemala in 1991: A Joint Report by the Legal Aid Office for Street Children of Casa Alianza (Covenant House) Guatemala and the Youth Procurator of the Public Ministry of Guatemala) 3 (1992); Casa Alianza, 1992 Annual Report 10 (1993).

1. Street Children: A Global Disgrace: Hearing Before the Select Committee on Hunger, House of Representatives, 102nd Cong., 1st Sess. 4-5 (1991) [hereinafter Street Children] (statement of Carlos Palacios, former street child currently working with Childhope in Guatemala).

2. Id. at 5 . 
international communities. ${ }^{3}$ The hard question is what to do.

This Article focuses on the problem of street children in Guatemala City. ${ }^{4}$ It provides a description of the way street children live and offers several theories as to why the situation arose. Finally, the Article critically discusses attempts to help the street children of Guatemala and proposes alternative solutions.

\section{STREeT CHILDREN IN GuATEMala}

It is important to begin by defining "street children." In the past, scholars lumped all children who spent extended time on the street under the term "street children." They made no distinction between children who worked on the streets and children who slept on the streets. ${ }^{5}$ Recently however, researchers and child advocates have acknowledged this distinction. UNICEF, for example, labels children who work during the day and return to their parents at night "children on the streets." "Children of the streets," in contrast, are those children who work and live on the streets while maintaining some bonds with their families but who essentially live self-sufficiently. ${ }^{6}$ Abandoned children are those who have absolutely no ties with their families. ${ }^{7}$ Childhope Foundation, an organization that works with street children

3. Id. (statement of Hon. Tony P. Hall, Representative from Ohio); Lori Lease, Killing the Children of the Third World, Wash. Post, Outlook, Apr. 21, 1991, reprinted in Street Children, supra note 1, at 76.

4. For information on street children in other countries, see generally Susanna Agnelli et al., Street Children: A Growing Urban Tragedy (1986) (discussing street children generally); Francisco Espert \& William Myers, UNICEF, Situation Analysis: Children in Especially Difficult Circumstances, 1988-1991 (1991) (discussing street children generally); Basilica Espínola et al., In the Streets: Working With Street Children in Asunción (1987) (discussing street children in Paraguay); Jill Swart, Malunde: The Street Children of Hillbrow (1990) (discussing street children in South Africa); Gilberto Dimenstein, Brazil: War on Children (1991); La Accion del Cisol con los Niños Trabajadores en la Ciudad de Loja, Documento Evaluativo para Unicef (1989) (discussing street children in Ecuador); Susana Zucchetti Canevaro, Los Niños en la Calle: Experiencia de Trabajo en Lima, Perú (1990) (discussing street children in Peru); Fabio Dallape, "You Are a Thief": An Experience With Street Children (1987) (discussing street children in Kenya); Peter Taçon, Survey on Street Children in Three Urban Centres of Namibia (1991) (discussing street children in Namibia).

5. Gary Barker \& Felicia Knaul, Exploited Entrepreneurs: Street and Working Children in Developing Countries 2 (Childhope-USA, Inc. Working Paper No. 1, 1991).

6. Id. (citing Executive Board, UNICEF, Exploitation of Working Children and Street Children (1986)).

7. Id. 
in cities throughout the Third World, ${ }^{8}$ labels all of these children "street children" and estimates that of all the street children in the world, $75 \%$ are children on the street, $20 \%$ are children of the street, and $5 \%$ are truly abandoned. ${ }^{9}$ For the purposes of this Article, the term "street children" refers to those children who are either of the street or truly abandoned.

\section{A. Estimated Number of Street Children}

Estimates of the number of street children vary considerably. ${ }^{10}$ Jorge Amardo Calderon ${ }^{11}$ estimates that there are 5000 street children in Guatemala, of whom 800 live in the capital. Casa Alianza, an orphanage that advocates for the rights of street children, places the number in the capital at about $3500 .^{12}$ The U.S. House of Representatives, Select Committee on Hunger, published a fact sheet in late 1991 stating that 5000 children live on the streets of Guatemala City and 1.4 million children work on those streets. ${ }^{13}$

Marilyn Rocky, National Director of Childhope-USA, a subsidiary of Childhope Foundation, estimates that unless something is done, the number of street children will double by the year $2010 .{ }^{14}$

\section{B. Lifestyle}

\section{Appearance}

Most street children are quite young. According to a report by Childhope, the average age of street children is 11.6 years old. The average age of boys is $\mathbf{1 2 . 3}$ years old, and the average age of girls is

8. Street Children, supre note 1, at 5 (statement of Marilyn Rocky, Regional Director, Childhope-USA).

9. Barker \& Knaul, supra note 5, at 2.

10. Id. This should not come as a surprise. Compiling statistics in Guatemala is difficult for a variety of reasons, including the fact that many Guatemalans do not speak Spanish. In addition, as pointed out above, what one study may call a street child, another may not. This is mentioned now so that the reader can treat all of the statistics in this paper as approximations, and not as exact measurements.

11. Interview with Jorge Amardo Calderon, Chief of the Minors Section of the National Police of Guatemala, in Guatemala City, Guatemala (Aug. 1993).

12. Memorandum from Marvin Rabanales Garcia, Casa Alianza staff (Aug. 26, 1993) (on file with author).

13. Street Children, supra note 1, at 53-54.

14. Id. at 7 (statement of Marilyn Rocky, Regional Director, Childhope-USA). 


\section{3 years old. ${ }^{15}$}

My personal observations ${ }^{16}$ indicated that street children have varied appearances. Many of the younger boys are shabbily dressed. Their clothes usually are too big, and they do not have sweaters or jackets for the night, which gets cold. If they have shoes, they are usually ripped with the laces missing. Their hair is often extremely short, not for fashion, but because civilians or members of the Guatemalan security forces commonly pour glue on their heads, leaving them with no choice but to shave off their hair. As boys get older, however, they tend to dress better. They wear nice shoes and more fashionable clothing. Some wear gold chains or other jewelry.

From a young age, girls tend to care more about how they look. Many wear make-up and skirts or dresses. They often wear some kind of feminine shoes. Of course not all girls fit the Latin image; some wear jeans and sneakers.

\section{Physical Health}

Not surprisingly, street children suffer from a variety of health problems. The most prevalent sicknesses are skin problems, respiratory disease, dental problems, and gastro-intestinal problems. Many of the abandoned children suffer from trauma or sexually-transmitted diseases. ${ }^{17}$

No statistics exist on how much street children eat in Guatemala, but street educators from Casa Alianza estimate that few eat more than once a day. ${ }^{18}$ In the neighboring country of Honduras, data was collected by Project Alternatives, a program for street children in the capital city of Tegucigalpa. The study showed that $7.2 \%$ of street children eat one meal per day, $36 \%$ eat two, and $56 \%$ eat

15. El Drama de los Niños de la Calle, Siglo Veintuno, July 24, 1993, at 2.

16. The information here and in the following paragraph came from personal observation and conversations with Casa Alianza street educators, in Guatemala City, Guatemala (Summer 1993).

17. Street Children, supra note 1, at 21 (statement of Dr. Donald Kaminsky, Executive Director, Project Alternatives).

18. The street educators form the bedrock of Casa Alianza's outreach program. They go out on the street with basic medical supplies and treat minor injuries. For more serious injuries, the street educators take the children to a Casa Alianza nurse and, if necessary, to the hospital. By visiting the children every day, Casa Alianza hopes that the street educators will gain the trust of the children so that they eventually may leave the streets to enter one of Casa Alianza's crisis centers. 
three. ${ }^{19}$ In addition, these Honduran children suffer from chronic malnutrition, and only $20 \%$ reach a normal height for their age. ${ }^{20}$ Whether the numbers are lower or higher in Guatemala, street children there certainly look unhealthy. They are extremely small for their age, and the boys appear sexually underdeveloped. The boys have no facial hair, their voices have not deepened, and they have little muscle. It is easy to mistake a youth of sixteen for a child of eight. ${ }^{21}$

Many of the children, both boys and girls, have cuts and scars. Some have carved the names of friends or lovers on their arms. Others have scars from street fights. Since most do not have access to proper medical care, cuts that could have healed easily are jagged and infected. I met one boy who had been smashed in the face with a bottle. Since he never received stitches, his wounds healed so that now he can barely open one of his eyes. Other children limp from improperly healed broken bones. A former nurse at Casa Alianza said that he had seen street children with broken legs take off their casts after only two weeks. ${ }^{22}$

Sexually-transmitted diseases (STDs) also pose a serious health problem. A 1991 study of 143 Guatemalan street children conducted by the Center of Orientation, Diagnosis, and Treatment of Sexually Transmitted Diseases and Casa Alianza found that 93\% of those studied admitted to having STDs. Of these, $78.3 \%$ admitted to having genital herpes, $46.64 \%$ gonorrhea, $27.3 \%$ papillomatosis, $13.29 \%$ vaginal trichomoniasis, $11.7 \%$ chancroids, and $69.9 \%$ scabies. $^{23}$ This same study found that none of the children reported using condoms. ${ }^{24}$

19. Street Children, supra note 1, at 10 (statement of Dr. Donald Kaminsky, Executive Director, Project Alternatives).

20. Id. at 21.

21. The information here and in the following paragraph is based on my personal observations.

22. Interview with Hector Dionicio Godinez, Casa Alianza staff, in Guatemala City, Guatemala (July 1993).

23. Center of Orientation, Diagnosis, and Treatment of Sexually Transmitted Diseases (1991) [hereinafter Joint Study] (summary of study on file with author).

24. Id. The study also found that $70 \%$ of the children had one to two partners a day, $4.2 \%$ had three to four partners, and $25.1 \%$ ( $92.31 \%$ girls) had more than four partners per day. Id. 


\section{Supporting Themselves}

To make money, many of the younger children beg. Some experts argue that a natural transition occurs from begging to stealing. ${ }^{25}$ The younger the child, the easier it is to arouse sympathy and collect money. When a child gets older, however, begging no longer offers a viable form of income and he or she must turn to something else. Many, especially boys, resort to stealing such items as wallets, sunglasses, and jewelry. ${ }^{26}$

Other street children work, helping bus drivers collect money, shining shoes, or dressing up as clowns and performing. Although some girls earn money by cleaning or doing odd jobs, many are prostitutes. Many work out of El Hoyo ("The Hole") in Zone 4 or in brothels in Zone $1 .^{27}$ Since girls usually are unskilled and uneducated, prostitution is one of the only livelihoods available to them. I saw no boy prostitutes in Guatemala, and I was told by Casa Alianza street educators that there were few.

\section{Living Conditions}

Carlos Palacios, a former street child in Bogotá, Colombia and now a street educator with Childhope in Guatemala, said the children live in places where they can "steal, beg and also disappear quickly. ${ }^{228}$ For example, many ten-to-fifteen-year-old children live in El Hoyo, a dirty, polluted, high-crime area around the bus terminal in Zone 4. Some children come to El Hoyo because of its reputation as a high-crime area with few policemen. ${ }^{29}$ Others were born there, the children of local prostitutes. ${ }^{30}$

25. Nancy Scheper-Hughes \& Daniel Hoffman, Kids out of Place, XXVII North American Congress on Latin America (NACLA) Report on the Americas, No. 6, at 16, 20 [hereinafter NACLA Report].

26. This information was gathered through conversations with street children, Casa Alianza street educators, and Casa Alianza staff, in Guatemala City, Guatemala (Summer 1993).

27. This was stated by Casa Alianza street educators and members of the Casa Alianza Legal Aid Office, in Guatemala City, Guatemala (July 1993).

28. Street Children, supra note 1, at 5 (statement of Carlos Palacios).

29. Interview with Wellington Tello, Casa Alianza street educator, in Guatemala City, Guatemala (July 1993).

30. Id. 
In El Hoyo, many children sleep indoors. ${ }^{31}$ They buy small bags of glue, priced between 50 centavos and one quetzal (about 10-20 U.S. cents), that keep them high for about an hour. In exchange for buying glue, they are allowed to sleep on the floor of a bar or house of prostitution. Sometimes they exchange stolen goods for a few nights of shelter.

Not all children sleep inside, however. I went to El Hoyo one night with a group of street educators from Casa Alianza. We saw a group of young boys sleeping together. Some were huddled under a blanket, others under a cardboard box, and still others under nothing at all.

Another set of boys, between the ages of ten and eighteen, spends its days at Concordia Park, across the street from the National Police Palace. The boys hang out most of the time next to the public bathrooms, inhaling glue and listening to the salsa and rap cassettes that blast from the vendors in the park. At night, they sleep under a nylon/plastic shelter at the corner of 18th Street and 6th Avenue.

Another group sleeps in the Central Park but spends most of its time in Trebol, a dirty, polluted area where buses stop on the way to Antigua. These children were characterized by Casa Alianza street educator Wellington Tello as older and more aggressive. They are between twelve and eighteen years of age and have often experienced severe family abuse and torture. Many have been beaten by people on the street.

The promise of shelter attracts some to Jocotales, an extremely poor neighborhood in Zone 6 . There, the children can sleep in or under parked buses. The children in Jocotales range in age from eleven to nineteen and generally have quite serious addictions to glue and other drugs.

The oldest children sleep in the "hotels," a cluster of cheap, dirty hotels in Zone 1 that charge about two dollars a night. Many of the girls who live in the hotels have babies or small children. They often sleep two to a room. The girls share their beds with their babies, and sometimes with a customer. According to street educator Wellington Tello, once children get older, they start to look and act differently. Most become more conscious of the way they dress and become more discreet about their drug addiction. They often form more

31. Unless otherwise indicated, the information here and in the remaining paragraphs of this section came from personal observation and interviews with Casa Alianza staff members, in Guatemala City, Guatemala (Summer 1993). 
serious relationships at this point, and some even get married.

Yet not all street children have broken their familial ties. Marilyn Rocky of Childhope estimates that only 5\% of street children in Central America are truly abandoned or completely disconnected from their families. ${ }^{32}$ Some sleep at home but spend their waking hours on the streets. Others go home when they have an emergency. One night, fourteen-year-old Justo got kicked in the head while he was sleeping. When he began to feel nauseous and could not eat, he went home. His ear drum had exploded from the blow. ${ }^{33}$

\section{Drugs}

An estimated $90 \%$ of Guatemalan street children are dependent on glue, paint thinner or other more powerful drugs such as pharmaceutical pills, ${ }^{34}$ beer, rum and rubbing alcohol. ${ }^{35}$ The majority inhale shoe glue, which they pour into plastic bags. Others breathe it straight from the bottle. Five quetzals will buy a bottle of glue big enough to keep a child high for about six hours. Paint thinner is also popular; children pour it onto rags and sniff. ${ }^{36}$

Many children try to hide their drug problem by covering their

32. Street Children, supra note 1, at 61 (statement of Marilyn Rocky, Regional Director, Childhope-USA).

33. I was with street educator Cristina Neff when some street children told us that Justo was dizzy and nauseous because of a head injury and had returned to his home. Cristina and I went to his neighborhood and found Justo in serious pain. He came with us to see the nurse at the refugio, or boys' crisis center, before being told that his injury was of such severity that a hospital visit was required. Cristina visited Justo in the hospital and said he was excited to receive candy and games to play. Although Justo tried hard to stay in the refugio, he left because he was unable to get over his addiction to glue. The last time I saw Justo was in front of a bus in Jocotales in early August 1993. We talked about his glue problem and I offered to give him my baseball hat if he quit. Justo was unable to accept my offer, and as far as I know, he is still in Jocotales.

34. In Guatemala, one does not need a prescription to get pharmaceutical drugs. Thus, barbiturates like valium are available over the counter.

35. Substance Abuse: International Experts Focus on Street Children, AIDS Weekly, May 9, 1994 [hereinafter Substance Abuse].

36. A 1991 study of 143 Guatemalan street children performed by Casa Alianza and the Center of Orientation, Diagnosis and Treatment of Sexually Transmitted Diseases found that $100 \%$ used inhalants (like shoe glue). The study also found that 96.5\% use drugs daily and that $3.5 \%$ use them weekly. See Joint Study, supra note 23 and accompanying text. 
bags or bottles with clothing. ${ }^{37}$ Some children have adopted this behavior as a way of avoiding harassment from the police and private citizens. Others are ashamed. This was evidenced by the fact that some street children hid their glue inside of their shirts or jackets when they were around the street educators. Since these street children knew that the street educators would not hurt them and that they would be given basic first aid and coloring books regardless of whether they inhaled glue, their behavior was more easy to explain as shame. Further, some of them talked of their plans to quit inhaling glue.

It would be a mistake to blame drug use for causing children to live on the streets; drugs constitute only part of the problem. A study in São Paulo, Brazil showed that the worse a child's relations were with his family and school, the more likely he or she was to use drugs. ${ }^{38} \mathrm{My}$ experience in Guatemala suggested that mistreatment and feelings of alienation drive children out of the home, and it is later on the street that they first try glue. Once they start, it is very difficult to stop. Glue and paint thinner are more physically addictive than cocaine or alcohol because they become part of a child's blood tissue. ${ }^{39}$ In addition, many of the children are psychologically hooked to the feeling of euphoria that inhalants provide. ${ }^{40}$ They rely on drugs to dull their feelings of hunger, cold, isolation, and rejection. ${ }^{41}$

Not only does addiction make it more difficult to leave the streets, but glue also has serious health consequences. In the short term, inhaling industrial glue results in lightheadedness, nausea, and loss of appetite. The long-term effects are much more extreme; inhaling glue has been linked to irreversible brain and kidney damage, lung damage, malnourishment, and a general decline in health. ${ }^{42}$

37. The information in this paragraph came from personal observation and interviews with Casa Alianza staff, in Guatemala City, Guatemala (Summer 1993).

38. Dimenstein, supra note 4 , at 3.

39. Telephone interview with Willard Goode, certified addiction specialist and hotline coordinator at Washington Area Council on Alcohol and Drug Abuse (Oct. 27, 1995).

40. Id.; interviews with street children and Casa Alianza street educators and staff, in Guatemala City, Guatemala (Summer 1993).

41. I learned this through interviews with street children and discussions with Casa Alianza street educators and staff, in Guatemala City, Guatemala (Summer 1993).

42. See Street Children, supra note 1, at 7 (statement of Marilyn Rocky, Regional Director, Childhope-USA); see also Substance Abuse, supra note 35. 


\section{Mistreatment}

Considered outcasts by Guatemalan society, street children often suffer severe mistreatment by both civilians and the police or army. ${ }^{43}$ It is common practice for police to pour glue in the children's hair and sometimes force them to drink it. Other children are yelled at or threatened. Some are refused service in restaurants or at food stalls. They are either ignored, stared at, or forced to leave.

But there are also much more serious cases of abuse. Children are beaten by family members, friends, and strangers. ${ }^{44}$ They are kidnapped, tortured, and even killed..$^{45}$ Sexual abuse and rape afflict both boys and girls. ${ }^{46}$ Exact numbers are hard to find. The police do not keep careful statistics, nor do other private or public organizations. ${ }^{47}$ The only organization that keeps systematic data is

43. I learned this through interviews with street children and discussions with street educators and other Casa Alianza staff, in Guatemala City, Guatemala (Summer 1993).

44. Id.; see Street Children, supra note 1, at 6 (statement of Marilyn Rocky, Regional Director, Childhope-USA).

45. Street Children, supra note 1 , at 6.

46. In the 1991 study of 143 street children by Casa Alianza and the Center of Orientation, Diagnosis, and Treatment of Sexually Transmitted Diseases, Joint Study, supra note 23, it was found that $100 \%$ of the children interviewed had been abused sexually. Of these, $53 \%$ were abused by family members, $5.95 \%$ by friends, $2.7 \%$ by neighbors, and $46 \%$ by strangers.

The study also found that $64.1 \%$ of the girls stated that their first sexual relationship was with their mother or father, $10.2 \%$ stated that it was with an uncle or aunt, $10.2 \%$ with a sibling, $2.6 \%$ with a friend, $5.1 \%$ with a boyfriend or girlfriend, and 7.7\% other. Id.

Of the boys interviewed, $7.7 \%$ stated that their first sexual relationship was with a parent, $22.1 \%$ with an aunt or uncle, $5.7 \%$ with a sibling, $6.7 \%$ with a friend, and $51.9 \%$ other. None stated that their first sexual relationship had been with a girlfriend or boyfriend. Id.

In her testimony before the House Committee on Hunger, Marilyn Rocky described a recent study in Guatemala in which 38 street girls were interviewed and asked questions about their sexuality. The study found that $95 \%$ of these girls reported having been sexually abused and $55 \%$ stated that they had been pregnant at least once. Street Children, supra note 1 , at 39.

47. The police do not compile exact statistics. Those provided by Jorge Amardo Calderon, Head of the Minors Section at the National Police, recorded only the number of complaints the police had received from Casa Alianza. The complaints were not broken down by type of abuse nor by the years in which they occurred. Officer Calderon's explanation for the crudeness of the numbers was that his office was overworked because it was also the Office for Disappeared Persons. Interview with Jorge Amardo Calderon, in Guatemala City, Guatemala (Aug. 1993). 
Casa Alianza, and it did not begin documenting abuses until $1990 .^{48}$ Taking the average number of abuses against street children that occurred in Guatemala City that were reported to Casa Alianza between 1990 and 1994: in 1990, the number of recorded abuses was $41 \%$ below the average; in 1991, $20 \%$ below the average; in $1992,49 \%$ above the average; in 1993, 28\% above the average; and in 1994, 30\% above the average. ${ }^{49}$

While these numbers look low, they must be used cautiously. The Legal Aid Office compiles Casa Alianza's statistics; unfortunately, however, many incidents of abuse are never brought to the office's attention. $^{50}$ I believe that children's reluctance to report violence stems from several sources. Some children may not have enough concrete information, like a badge or license number, to make giving a report worthwhile. Others may not want to go through lengthy legal proceedings. Still others may be afraid. Fear of retaliation from the police or army may thwart any desire they might have to make an official complaint.

\section{What Brings Them to the Streets}

To understand what brings children to the streets, it is first necessary to look more generally at some of the problems afflicting Guatemala. The most critical problems are poverty, high birth rate, land distribution, government and military repression, urbanization, lack of education, lack of economic opportunity, child labor, and lack of unions. ${ }^{51}$

\section{Poverty}

Based on indices of income distribution and public services, the United Nations called Guatemala among the four worst countries in

48. Crimes recorded by Casa Alianza include the following: abuses of authority, illegal detentions, murders, physical attacks resulting in injury, threats, intimidation, rapes, and kidnappings. In 1990, there were 22 recorded abuses against street children; in 1991, 30; in 1992, 56; in 1993, 31; in 1994, 49.

49. Casa Alianza statistics (on file with author).

50. See Casa Alianza, 1992 Annual Report, supra note **, at 2.

51. Street Children, supra note 1, at 6-7 (statement of Marilyn Rocky, Regional Director, Childhope-USA). 
the world. ${ }^{52}$ Ironically, Guatemala has a gross per capita product more like that of median developing countries. ${ }^{53}$ In Guatemala, a minute section of the population is extraordinarily rich, and most of the rest are extremely poor. ${ }^{54}$

Eighty percent of Guatemalan families live in poverty ${ }^{55}$ and 5.1 million of Guatemala's population of ten million were deemed by the Guatemalan Attorney for Human Rights to be living in subhuman conditions. ${ }^{56}$ The Central American Council for Housing called Guatemala the country with the worst housing situation in Central America ${ }^{57}$ Fifty percent of the population lack minimal quarters; $62 \%$ of the population have only dirt floors; and more than $50 \%$ of families have only one room for the entire family. ${ }^{58}$ In addition, over half of the existing housing do not have water supply services, and 63\% percent do not have latrines. ${ }^{59}$

Health also constitutes a serious problem in Guatemala. Government health programs cover only $14 \%$ of the population, ${ }^{60}$ and most people cannot afford to go to a private hospital..$^{61}$ Even if they have access to a public hospital or clinic, people still are not guaranteed help. Waiting lines are long, and it is not uncommon for public hospitals to run out of medicine for weeks at a time. ${ }^{62}$

52. Inter-American Commission on Human Rights, Fourth Report on the Situation of Human Rights in Guatemala 5, U.N. Doc. OEA/Ser.2/V/l.83 (1993) [hereinafter InterAmerican Commission on Human Rights]. For a more detailed examination of poverty in Guatemala, see Appendix A.

53. Inter-American Commission on Human Rights, supra note 52, at 5 (quoting United Nations Development Programme (UNDP), Human Development Report 1993, at $135-36(1993))$.

54. America's Watch, Human Rights in Guatemala: No Neutrals Allowed 1 (1982) [hereinafter Neutrals].

55. See Inter-American Commission on Human Rights, supra note 52, at 8.

56. Id. at 8 (quoting Attorney for Human Rights, Los Derechos Humanos: un Compromiso por la Justicia y la Paz 1987-1992).

57. Id.

58. Id.

59. Id.

60. Id. at 5 (citing Carmelo Mesa Lago, Aspectos Economicos Financieros para la Seguridad Social en America Latina y el Caribe, in ECLAD Equidad y Transformacion Productiva (1992)); SEGEPLAN \& UNICEF, Analysis of Situation of Women and Children (1991).

61. This information was obtained through personal interviews with locals in Guatemala from July 1990 to August 1991. Further conversations with Guatemalans in the summer of 1993 confirmed this observation.

62. During the year in which I lived in Guatemala, the public hospitals frequently lacked medicine. 
Because of the poor living standards and lack of medical care, many people suffer. Infant mortality is at $6 \%,{ }^{63}$ with the major causes of death being diarrheic diseases, acute respiratory infections, and malnutrition. ${ }^{64}$ Cholera has also been a major killer in Guatemala. ${ }^{65}$ In 1992 alone, there were almost 15,000 cases. $^{66}$

Malnutrition is another serious problem in Guatemala. In 1987, $33.5 \%$ of the population suffered from malnutrition, and of these, $57.8 \%$ suffered from chronic malnutrition. ${ }^{67}$ Of children between five and nine who attend school, $37 \%$ suffer from malnutrition. ${ }^{68}$

\section{High Birth Rate}

Guatemalan women have an average of 6.4 live births. ${ }^{69}$ According to the National Family Planning Center, the 1990 population of 9.2 million will quadruple to 34.3 million in the first quarter of the 21 st century. ${ }^{70}$ Such a dramatic birth rate only exacerbates the plight of Guatemala's poor, making it harder for parents to support their growing families and, thus, more likely that children will be forced to go out into the streets and work. ${ }^{71}$

63. United Nations Development Programme, Human Development Report 1993: Investing in Health: World Development Indicators, Table 28 (Health and Nutrition), at 292 (1993).

64. Inter-American Commission on Human Rights, supra note 52, at 8 (citing official Pan American Health Organization, Health Conditions in Latin America (1990)).

65. Cholera is an acute intestinal disease that can cause death within a few hours from onset if not treated properly. It is usually transmitted through food or water that has been contaminated with feces or vomitus. The incubation period lasts between $a$ few hours and five days. It is prevalent in areas that do not have clean drinking water (or the ability to sterilize it) and do not have the ability to disinfect or heat up food. Ironically, treatment of cholera is relatively easy. The afflicted must drink or receive intravenously a solution comprised primarily of water, sugar, and salt. American Public Health Association, California State Department of Health Services, Control of Communicable Diseases in California 105-10 (1983).

66. Inter-American Commission on Human Rights, supra note 52, at 8.

67. Id. at 5 (citing Pan American Health Organization, Health Conditions in Latin America, Washington, D.C. (1990)).

68. Id. at 8.

69. David Stoll, Between Two Armies in the Ixil Towns of Guatemala 15 (1993) (citing Jorge Arias de Blois, Cronica, Oct. 6, 1989, at 15).

70. Id.

71. See Barker \& Knaul, supra note 5, at 6-7. 


\section{Land Distribution}

Although Guatemala has fertile land, people are severely malnourished. ${ }^{72}$ In part, this is because of disparities in land ownership. Currently, $2.1 \%$ of the farm property owners possess $72 \%$ of the farmland and receive $90 \%$ of the farm credit. ${ }^{73}$ This land is divided into huge plantations worked by predominantly indigenous labor at extremely low wages. ${ }^{74}$ Although it would be possible to use this land to grow low cost, nutritious foods, such as corn and beans, most plantation owners do not. ${ }^{75}$ Instead, they devote the land to export crops, such as coffee, bananas, and pineapples. ${ }^{76}$ Only food that is of a quality too low to export appears in the local markets. ${ }^{77}$

Those who are lucky enough to own land often do not have enough to sustain themselves. ${ }^{78}$ There are 548,000 small farms in Guatemala, with an average size of 4.6 acres. ${ }^{79}$ These farms receive only $4 \%$ of the farm credit. ${ }^{80}$ Consequently, significant numbers of people are forced to leave their land to work as seasonal laborers on coffee or sugar plantations. ${ }^{81}$ For the past several years, however, plantations have been swarmed with people seeking work, making it harder for people to make the money they need to survive. ${ }^{82}$ The lack of opportunity drives many people into the cities in search of jobs to

72. Telephone interview with Rachel Garst, Assistant for Guatemala, Washington Office on Latin America (Oct. 24, 1995). See also supra notes 64-68 and accompanying text.

73. Inter-American Commission on Human Rights, supra note 52, at 6.

74. Interview with Rachel Garst, supra note 72.

75. Id.

76. Id.

77. Id.

78. A 1980 USAID study concluded that $90 \%$ of people are living on land that is too small to give them income sufficient to support themselves. Lawyers Committee for Human Rights, Abandoning the Victims: The UN Advisory Services Program in Guatemala 21 (1990) [hereinafter Lawyers Committee for Human Rights] (citing U.S. Agency for International Development, Land and Labor in Guatemala (1982)).

79. Inter-American Commission on Human Rights, supra note 52, at 6.

80. Id.

81. Lawyers Committee for Human Rights, supra note 78, at 21. Jean-Marie Simon, Eternal Spring-Eternal Tyranny 25-26 (1987); Donald T. Fox, Human Rights in Guatemala 18 (n.d.) (report of a mission to Guatemala in June 1979 on behalf of the International Commission of Jurists).

82. Telephone interview with Victoria Rich, Guatemala Human Rights Commission (Nov. 20, 1995). 
support themselves. $^{83}$

The cause for this disparity is multifold, but the simplest answer is greed. As in the rest of the Americas, Europeans have taken large chunks of land from the indigenous people. ${ }^{84}$ When private landowners have wanted more land, they have simply taken it. ${ }^{85}$ Even if those farming the land have been there for many generations, their claims are not honored. If they protest their eviction, indigenous people are in danger of being killed. ${ }^{86}$

\section{Government and Military Repression}

Another important factor in explaining how children get on the street is military repression. For the last thirty years, Guatemala has been in a state of civil war. In an effort to free themselves from an oppressive economic and political situation, Guatemalan guerrillas have fought for revolution. ${ }^{87}$ The army and other paramilitary forces have responded brutally. ${ }^{88}$ Anyone suspected of being or aiding a guerrilla has been at risk of being "disappeared" 89 or killed. Between 1966 and 1986, 100,000 civilians were killed and 38,000 disappeared..$^{90}$ Politicians, priests, journalists, human rights workers,

83. Id.

84. Fox, supra note 81 , at 2 .

85. Lawyers Committee for Human Rights, supra note 78, at 22; see also Neutrals, supra note 54 , at 10.

86. Neutrals, supra note 54, at 10.

87. Telephone interview with Francisco Ortega Lopez, Representative to Washington of the Unidad Revolucionaria Nacional Guatemalteca (UNRG) (Nov. 20, 1995). The UNRG is the major guerilla organization in Guatemala. The four existing Guatemalan insurgency groups united to form the UNRG in 1982. See Simon, supra note 81 , at 80 .

88. Americas Watch, Little Hope: Human Rights in Guatemala January 1984 to January 1985, at 19-20 [hereinafter Little Hope].

89. The term "desaparecido," meaning "disappeared," originated in Guatemala. As Jean-Marie Simon states, "[t]he term desaparecido... acquired its grammatical versatility as both a verb and participle ('to be disappeared,' 'he was disappeared') in Guatemala almost a decade before the term was exported to Chile and Argentina. As a result, there is hardly a Guatemalan alive who cannot name at least a dozen friends, relatives or colleagues killed or 'disappeared' over the past decade." Simon, supra note 81 , at 14.

90. Americas Watch, Closing the Space: Human Rights in Guatemala May 1987-October 1988, at 5 (1988) (quoting Brook Larmer, Guatemala's Moderate Chief Went Too Far for Far Right, Christian Sci. Mon., May 17, 1988). 
teachers, trade unionists, and peasants were often targeted. ${ }^{91}$ Hundreds of victims, sometimes still alive, were dropped into the crater of Pacaya, Guatemala's most famous active volcano. ${ }^{92}$

Over $\mathbf{4 0 0}$ towns and villages have been razed in an effort to rid Guatemala of leftist tendencies. ${ }^{93}$ One million people were displaced. ${ }^{94}$ Some fled the country or went into hiding. ${ }^{95}$ Others moved to different rural communities, model villages, ${ }^{96}$ or Guatemala City. ${ }^{97}$

This regime of violence has affected children in particular. Experts estimate that 45,000 to 60,000 parents were killed between 1978 and 1985 , leaving 50,000 widows and 150,000 orphans. ${ }^{98}$ Additionally, the violence has had profound psychological consequences. Prolonged exposure to violence results in serious psychological problems, including "psychic numbing, social withdrawal, an inability to concentrate, thought disorders, nightmares, night terrors, [and] aggressive behaviors." ${ }^{n 9}$ With intervention, these children have a chance of recovering. ${ }^{100}$

91. See Larry Towell, House on Ninth Street 12 (1994); see also Simon, supra note 81, at 15; Little Hope, supra note 88, at 5-18.

92. Simon, supra note 81 , at 13 .

93. Inter-American Commission on Human Rights, supra note 52, at 75. See generally Amnesty International, Guatemala: The Human Rights Record 53 (1987); see also Beatriz Manz, Refugees of a Hidden War: The Aftermath of Counterinsurgency in Guatemala 83-89, 140-41 (1988).

94. Inter-American Commission on Human Rights, supra note 52, at 63.

95. By 1984, an estimated 150,000 people had fled to Mexico. Even there, however, they were not safe. On several occasions, they were attacked by the Guatemalan military. Little Hope, supra note 88 , at 31-32.

96. Model villages were constructed to house refugees and to allow the military to prevent the influx of subversives into rural peasant communities. See Simon, supra note 81 , at 154-55, 235-36.

97. Victor Perera, Unfinished Conquest: The Guatemalan Tragedy 17-18 (1993).

98. Id. at 6 (quoting Chris Kruger \& Kjell Enge, Washington Office on Latin America, Security and Development Conditions in the Guatemalan Highlands 2 (Aug. 1985)).

99. Children of War: Victims of Conflict and Dislocation: Hearing Before the Subcomm. on Children, Family, Drugs and Alcoholism of the Senate Comm. on Labor and Human Resources, 101st Cong., 2d Sess. 50 [hereinafter Children of War] (prepared statement of Neil Boothby); see also Perera, supra note 97, at 95-101 (statement of Adrianne Aron, Ph.D).

100. Children of War, supra note 99, at 51-52. 


\section{Urbanization}

Rapid urbanization is one of the primary causes of the street child phenomenon. Currently, $40 \%$ of all Guatemalans live in cities, and the average annual growth rate of urban areas between 1980 and 1991 was $3.5 \% .^{101}$ When people leave rural areas for the cities, they most likely will settle in extremely poor neighborhoods; some estimate that within twenty years, more than half of the population in developing countries will be living in urban slums. ${ }^{102}$ In addition, families who immigrate to cities are less likely to have a social network of extended family or friends on which they can depend. ${ }^{103}$ Many children are forced to go onto the streets in order to contribute money to their families' paltry income. ${ }^{104}$ Under the poverty and pressure of urban life, the family unit begins to disintegrate. ${ }^{105}$

6. Lack of Education

Illiteracy is a serious problem in Guatemala. Next to Haiti, Guatemala has the highest illiteracy rate in Central America and the Caribbean. In $1990,45 \%$ of people over the age of fifteen could not read or write. ${ }^{106}$

Sadly, it does not look as though the situation will improve. In 1980 , only $58 \%$ of children between the ages of six and eleven attended school. ${ }^{107}$ Recent statistics show no improvement. ${ }^{108}$ Of the children who started elementary school in $1978,63 \%$ had dropped out by 1984 , and in rural areas the number was $85 \% .{ }^{109}$ Girls are worse off than boys. Only $49 \%$ of girls living in rural areas enroll in

101. United Nations Development Programme, supra note 63, Table 31 (Urbanization), at 298.

102. Street Children, supra note 1, at 53 (U.S. House of Representatives, Fact Sheet on Street Children).

103. See id. at 7 (statement of Marilyn Rocky, Regional Director, Childhope-USA); Agnelli, supra note 4, at 52-53.

104. See Street Children, supra note 1, at 84 (statement of Marilyn Rocky, Regional Director, Childhope-USA); Agnelli, supra note 4, at 52-53.

105. See Street Children, supra note 1, at 18 (statement of Marilyn Rocky, Regional Director, Childhope-USA).

106. Inter-American Commission on Human Rights, supra note 52, at 6.

107. Id.

108. Id.

109. Id. at 9. 
elementary school, and few graduate. ${ }^{110}$ Despite these problems, in 1985, only $1.8 \%$ of Guatemala's Gross Domestic Product was devoted to education. ${ }^{111}$

\section{Lack of Economic Opportunity}

Even worse than the poverty is the seeming impossibility of the poor to overcome it. In 1990, the unemployment rate was $41 \%$, up from $31.2 \%$ in 1980 . $^{112}$

The majority of the population works at dismal salaries. A minimum wage was introduced in 1973 , but it covered only permanent workers. ${ }^{113}$ The wage was set at 1.2 quetzals per day, which at the time was equivalent to U.S. $\$ 1.20 .^{114}$ In 1982 , sugar and cotton workers went on strike to bring the wage up to 3.2 quetzals per day. This was unenforced, and the official wage was only 2.3 quetzals per day. ${ }^{115}$

In 1991 , the minimum wage was increased by $78.5 \% .^{116}$ Consequently, the minimum wage of farm workers was raised to 11.60 quetzals (U.S. \$2.00) per day, including a mandatory bonus. ${ }^{117}$ Similarly, the minimum wage of industrial workers was raised to 14 quetzals (U.S. \$2.42) for an eight-hour work day, ${ }^{118}$ with a required hourly bonus. ${ }^{119}$ Despite this significant increase, approximately $70 \%$ of those employed live below the Guatemalan poverty line. ${ }^{120}$

The situation is particularly bad for female workers. Although the Guatemalan Constitution states the principle of gender equality, women are routinely paid less then their male counterparts and are discriminated against in seeking employment. ${ }^{121}$ This partly explains

110. Id.

111. Id. at 6 .

112. Id. at 8.

113. Lawyers Committee for Human Rights, supra note 78, at 21.

114. Id.

115. Id. at 21-22.

116. U.S. Dep't of State, Guatemala Human Rights Practice: 1993 Report 43 (1994).

117. Id.

118. Even though the legal work day is eight hours and the work week is 44 hours, people work much longer. Human rights groups and trade union leaders assert that workers are coerced into working overtime or even are given drugs so they can work longer. Id. at $43-44$.

119. Id.

120. Id.

121. Id. at 36. 
why women, who make up more than half the population, constitute a mere $24 \%$ of those engaged in paid labor. ${ }^{122}$ Of those who work, most work in relatively low-wage jobs, such as textiles, agriculture, and retail. ${ }^{123}$ Furthermore, more women than men work in the informal sector of the economy, where wages and benefits usually are quite low. ${ }^{124}$ A survey conducted in 1989 showed that women working in Guatemala City were underrepresented in high income jobs. ${ }^{125}$

The present bleak situation stems in part from the economic crisis of the 1980s. During the 1980s, the economies of Central America, including Guatemala, were gravely affected by the 1979 oil shock, the resulting recession, lower prices of Central American exports (i.e., bananas, coffee, sugar, and cotton), ${ }^{126}$ and higher interest rates. ${ }^{127}$ Until 1978, the Guatemalan economy had been steadily increasing in productivity, but growth fell drastically during the period of economic crisis that followed. ${ }^{128}$

Together, these changes have had a profound effect on Guatemala. Between 1980 and 1989, the poverty rate increased from $63 \%$ to $77 \%$ of the population. ${ }^{129}$

\section{Child Labor}

Although the Guatemalan Constitution forbids employment of minors below the age of fourteen, child labor is prevalent. ${ }^{130}$ Many families are unable to subsist without the financial contribution of

122. Id.

123. Interview with Rachel Garst, supra note 72.

124. U.S. Dep't of State, supra note 116, at 36.

125. Id.

126. Victor Valverde et al., Institute of Nutrition of Central America and Panama (INCAP), Final Report, Minimum Wage Law and Nutritional Status in Guatemala 4 (1987).

127. See Street Children, supra note 1, at 94 (prepared statement of Aaron Williams, Deputy Assistant Administrator, Latin America and the Caribbean Bureau, USAID). For a detailed analysis of this situation, see Enrique Delgado Sieca, The Impact of the Economic Crisis in Central America and in Guatemala (Latin American and Caribbean Center of Florida International University, April 1985).

128. The growth in GDP in Guatemala was 5.9\%. See Sieca, supra note 127.

129. Inter-American Commission on Human Rights, supra note 52, at 8.

130. U.S. Dep't of State, supra note 116, at 42-43. 
their children. ${ }^{131}$ Consequently, 1.6 million children are working to support themselves or to contribute to their families' income. ${ }^{132}$

The work that children do depends on their location. Since children are usually uneducated ${ }^{133}$ and untrained, ${ }^{134}$ few opportunities exist for them. Some work in the fields with their parents; others work away from home. Many girls are muchachas, servants who cook and clean. Some work only during the day and return to their families at night, but many sleep in the homes where they work, getting one day off a week. Others work at restaurants or stores. Boys are more likely to work on their own. Many sell newspapers or candy. They also shine shoes, haul garbage, and beg. ${ }^{135}$

Unfortunately, due to structural problems with the labor court system and the dearth of qualified labor inspectors, laws governing the employment of minors rarely are enforced. ${ }^{136}$ Consequently, thousands of children are vulnerable to exploitation. ${ }^{137}$ They receive no benefits, severance pay, or vacations, and they have no social insurance. ${ }^{138}$ In addition, many work below the minimum wage level. ${ }^{139}$

Although it is certainly not the case that all child workers will become street children, working increases the risk. Some children will become associated with other street children, start using drugs, and then decide to leave home. ${ }^{140}$ Others may leave home because of the pressure they feel to earn money and the mistreatment they suffer when they do not earn as much as they are expected to. ${ }^{141}$

Yet no easy solution exists for the problem of child labor. As a

131. Street Children, supra note 1, at 78-80 (statement of Marilyn Rocky, Regional Director, Childhope-USA).

132. Inter-American Commission on Human Rights, supra note 52, at 9.

133. See supra notes 106-11 and accompanying text.

134. Street Children, supra note 1, at 6 (statement of Marilyn Rocky, Regional Director, Childhope-USA); interviews with Casa Alianza street educators, in Guatemala City, Guatemala (Summer 1993).

135. Street Children, supra note 1, at 6 (statement of Marilyn Rocky, Regional Director, Childhope-USA).

136. U.S. Dep't of State, supra note 116, at 42-43.

137. Id.

138. Id.

139. Street Children, supra note 1 , at 6 .

140. Interviews with Casa Alianza street educators, in Guatemala City, Guatemala (July 1993).

141. Id. 
report by Childhope discusses, some forms of child labor are not exploitative and may even provide a more fruitful future than a formal education. ${ }^{142}$ Children provide an important source of additional income to their families. As the report states, "even when the work of street children is harmful however, it may be crucial to the survival of millions of families in developing countries. . . Consequently, any effort to eradicate the work of children in the informal sector without improving the income generating potential of the family will be ineffective. ${ }^{143}$

\section{Lack of Unions}

Improving work conditions is not easy. For many years, people were afraid of participating in unions because of the government's response. Many union organizers and members have been killed and disappeared. ${ }^{144}$ Although no union leaders were killed in 1993, a number were threatened, kidnapped, or physically abused. ${ }^{145}$ Today, although union membership is up in Guatemala, it still remains low in comparison with the United States, which is itself a relatively nonunionized country. ${ }^{146}$ Only $8 \%$ of the Guatemalan labor force was organized in 1988 . $^{147}$

Some improvements have been made, however. In 1992, the 1947 Labor Code was amended to do a number of things, including easing the process by which unions achieve legal status, increasing the penalties for employers who violate labor laws, and strengthening the ability of the Ministry of Labor and organized labor to enforce labor violations. ${ }^{148}$ Despite these positive changes, the International Labor Organization (ILO) Committee of Experts has criticized the Guatemalan Labor Code for requiring a vote by at least two-thirds of the workers for a strike to be legal. The ILO also opposes the

142. See generally Barker \& Knaul, supra note 5.

143. Id. at 13 .

144. Towell, supra note 91 , at $119-22$.

145. U.S. Dep't of State, supra note 116, at 40.

146. In the United States, $17 \%$ of the labor force is unionized. United Nations Development Programme, supra note 63, Table 38 (Employment). In contrast, the unionization rates of many other countries are significantly higher. For example, the percentage of the workforce that is unionized in a sampling of other countries is, respectively: Sweden, 85\%; Iceland, 78\%; Denmark, 73\%; Japan, 27\%; Germany, 34\%; and the United Kingdom, 42\%. Id.

147. Lawyers Committee for Human Rights, supra note 78, at 48.

148. U.S. Dep't of State, supra note 116, at 38. 
prohibition of strikes by agricultural workers at harvest time and any other strike that the government determines will seriously affect the national economy. ${ }^{149}$

\section{Combining These Factors: Dysfunctional Families}

Although the factors described above may contribute in isolation to the problem of street children, they often combine to create stressful family situations. ${ }^{150}$ When families come to the capital in search of safety or a good job, they usually are disappointed. Since parents often have only farming skills, they are unable to get jobs that earn adequate money to support the family. This creates financial strain and ultimately forces the children to go out and work. ${ }^{151}$ In addition, the family is usually living in extreme poverty, with no running water or electricity. The stress of poverty is compounded by the fact that families do not enjoy the same support network that they had in the countryside. ${ }^{152}$ Without extended families, many parents have no support when a job interferes with child care or an emergency occurs. All of these factors create stress on the parents which, in many cases, leads them to drink or to become abusive. ${ }^{153}$

Another consequence of the poverty and the pressure is that some men abandon their families. Abandonment is more likely when families move from rural areas to urban slums or when one or both parents must migrate in search of employment. ${ }^{154}$ For the children, the consequence of losing a father can be traumatic. One study showed that single women with large numbers of children are at the highest risk of having their children work or live on the street. ${ }^{155}$ Some children are forced to leave the house in search of work; others flee

149. Id.

150. See Agnelli, supra note 4, at 47-49; Street Children, supra note 1 , at 5 (statement of Carlos Palacios, former street child); id. at 5-7 (statement of Marilyn Rocky, Regional Director, Childhope-USA); id. at 7 (statement of Donald C. Kaminsky, Executive Director, Project Alternatives); id. at 1 (opening statement of Hon. Tony $P$. Hall, Rep. from Ohio); id. at 66 (citing Lori Heise, Killing the Children of the Third World, Wash. Post, Outlook, April 21, 1991).

151. See supra notes $130-43$ and accompanying text.

152. See supra note 103 and accompanying text.

153. Id.

154. Barker \& Knaul, supra note 5, at 7.

155. Agnelli, supra note 4 , at 50. 
stepfathers who, at best, care little for them and, at worst, abuse them. ${ }^{156}$

Whether fleeing a two-parent family that has disintegrated due to poverty and pressure or fleeing an abusive stepfather, most street children have been emotionally, sexually, and physically abused. ${ }^{157}$ Although no statistics are available from Guatemala, studies done in other countries reflect the violence that street children have faced at home. One researcher interviewed fifty-three girls living on the streets of Brazil and found that $30 \%$ were orphans, $35 \%$ had experienced sexual abuse in the home, usually from a stepfather, $80 \%$ had no contact with their fathers, and $50 \%$ identified alcoholism as a problem in their families. Of the fifty-three girls interviewed, all but three had come from broken homes. ${ }^{158}$ Another study conducted in Bogotá, Colombia found that of the 196 children interviewed, $55 \%$ had fled their homes because of violence, and of these, 33\% said that the perpetrator was either a stepfather or a boyfriend of their mother. ${ }^{159}$ For children such as these, the street offers a welcome sanctuary from the home.

\section{Past Attempts at Problem-Solving}

Both the Guatemalan government and various nongovernmental organizations have attempted to help the street children in Guatemala. Although many of these attempts have been wellmotivated, they have achieved limited success.

\section{A. Government Efforts}

With the election of Vinicio Cerezo as President in 1985, the

156. One survey conducted in Colombia found that $72 \%$ of street children stated that their biological father was missing and $60 \%$ stated that a stepfather was living in the home. See Barker \& Knaul, supra note 5, at 7 (citing J. Felsman, Risk and Resiliency in Childhood: The Lives of Street Children, in The Child in our Times (1989)). See also Agnelli, supra note 4, at 48-49.

157. This information comes from my own personal conversations with street children, in Guatemala City, Guatemala (Summer 1993), and from those of other Casa Alianza workers.

158. Gilberto Dimenstein, Little Girls of the Night, in NACLA Report, supra note 25 , at 29,31 .

159. Barker \& Knaul, supra note 5, at 7 (citing J. Harrison, Muchachos de la Calle (Gamines): Special Focus: Drug Addiction (1987) (report submitted to the InterAmerican Drug Abuse Control Commission, Organization of American States, Washington, D.C.)). 
Guatemalan government began struggling to improve its human rights record. The government enacted a new constitution, which guaranteed more rights to the Guatemalan people and created a variety of governmental human rights organizations. ${ }^{160}$ But it was not until 1990, after the death of Nahaman Carmona Lopez, that the government began to focus on street children. ${ }^{161}$ Casa Alianza's efforts to prosecute Nahaman's killers brought a great deal of media attention to street children. ${ }^{162}$ Letters started pouring in from around the world, and the Guatemalan government was pressured to improve the situation. ${ }^{163}$ As evidence of this, on December 10, 1991, the Presidential Commissioner for International Cooperation told President Serrano Elias that the second most significant reason for the reduction of foreign aid to Guatemala was violence against street children. ${ }^{164}$

Although the Guatemalan government geared some actions specifically toward street children, for the most part, their efforts have been aimed at the human rights situation in general. Since ending the phenomenon of street children requires grappling with many deep and complex problems in Guatemala, ${ }^{165}$ it merits looking at these more general reforms.

\section{The 1985 Constitution}

The 1985 constitution promises that life will improve for Guatemalans. ${ }^{166}$ It guarantees citizens many kinds of protection, including Article 29, which allows people to challenge the constitutionality of a government decision. Article 66 says that " $[t]$ he

160. See infra notes $166-68$ and accompanying text.

161. Interview with Bruce Harris, Director of Casa Alianza, in Guatemala City, Guatemala (July 1993).

162. Id.

163. Id.

164. Casa Alianza, 1991 Annual Report, supra note **, at 13.

165. See supra notes 51-159 and accompanying text.

166. The new constitution was approved on May 31, 1985, by the Guatemalan Assembly but did not take effect until January 14, 1986, when newly-elected Vinicio Cerezo took office. Hon. George C. Edwards \& William J. Butler, Guatemala: A New Beginning: Report of a Mission on Behalf of the American Association for the International Commission of Jurists 3 (1987). For an English translation of many parts of the Guatemalan Constitution pertinent to human rights issues, see The Minnesota Lawyers' International Human Rights Committee, Justice Suspended: The Failure of the Habeas Corpus System in Guatemala 120 (1990) [hereinafter Minnesota Lawyers' Report]. 
State recognizes, respects and encourages the indigenous peoples of Guatemala." ${ }^{\text {G67 }}$ The constitution also says that indigenous people should be able to maintain their land in its traditional form, and that cooperatives should be given extra support. ${ }^{168}$

\section{Ratifying International Human Rights Law}

Guatemala has shown at least a superficial commitment to improving the human rights situation by ratifying various human rights conventions. In January 1987, Guatemala was the first member country of the Organization of American States to ratify the American Convention to Prevent and Punish Torture. ${ }^{169}$ Guatemala did not sign the Covenant on Civil and Political Rights, but it did sign the International Covenant on Economic, Social and Cultural Rights in May $1988 .{ }^{170}$ Most importantly, Guatemala was the sixth member country of the United Nations to ratify the Convention on the Rights of the Child. ${ }^{171}$ In 1990, Guatemala signed the World Declaration for the Survival, Development, and Protection of Children. ${ }^{172}$ Although Article 3 of Guatemala's 1985 constitution gives precedence over national law to human rights treaties and conventions that have been ratified by Guatemala, these treaties have not, as yet, been taken seriously. ${ }^{173}$

\section{Human Rights Commission of Congress}

The Guatemalan Constitution created the Human Rights Commission of Congress as a means of improving the human rights situation in Guatemala. ${ }^{174}$ In pursuit of this end, the Commission has several responsibilities. First, it seeks to improve the understanding of human rights within Guatemala through studies, seminars, and investigations. Second, it must investigate complaints

167. Inter-American Commission on Human Rights, supra note 52, at 34 .

168. Id. at 32-33.

169. Lawyers Committee for Human Rights, supra note 78, at 38.

170. Id.

171. Casa Alianza 1991 Annual Report, supra note **, at 2.

172. Street Children, supra note 1, at 49 (statement of Per Engebak, American Representative, UNICEF).

173. Inter-American Commission on Human Rights, supra note 52, at 13-14. 1995).

174. Telephone interview with Anne Manuel, Human Rights Watch/Americas (Oct. 
brought to its attention by national and international sources and must recommend solutions. Finally it is responsible for evaluating existing Guatemalan law in relation to existing national and international human rights norms. ${ }^{175}$

Despite the initial feeling of hope, the Commission has achieved limited success. In part, the problem is due to fear; vindicating human rights is a dangerous business in Guatemala, and Commission members have good cause to fear for their lives. ${ }^{176}$ Furthermore, the Commission is not well funded. Its budget of U.S $\$ 200$ a month ${ }^{177}$ is so low that the president of the Commission, Oliverio Garcia Rodas, can only afford to pay two staff people, and he must get assistance from the employees of his private law office. ${ }^{178}$ Finally, the Commission is not taken very seriously by the Guatemalan Congress. It has a limited mandate which makes it ineffective. ${ }^{179}$

\section{The Human Rights Commissioner}

The 1985 constitution created the position of human rights commissioner, or ombudsman. ${ }^{180}$ The ombudsman is selected by the Guatemalan Congress from one of three candidates nominated by the Human Rights Commission. ${ }^{181}$ In addition to the official ombudsman, there are five regional offices staffed by lawyers who have received one month's training. ${ }^{182}$

The ombudsman's role is to receive and evaluate complaints, carry out initial investigations, and then turn cases over to the proper judicial authorities. He can intervene to speed up a judicial investigation if the need arises. The ombudsman also must publish an annual report. ${ }^{183}$ Most importantly, the ombudsman has significant power to investigate individual allegations of human rights abuses. He can investigate any premises or installations, whether public or

175. Lawyers Committee for Human Rights, supra note 78, at 34-35.

176. Americas Watch, supra note 90 , at 57.

177. Id.

178. Minnesota Lawyers' Report, supra note 166, at 28.

179. Americas Watch, supra note 90 , at 57.

180. Guatemala: The Prospects for Peace: Hearing Before the Subcomm. on Western Hemisphere Affairs of the House Comm. on Foreign Affairs, 103rd Cong., 1st Sess. 36-37 (1993) [hereinafter Guatemala Prospects] (statement of Ernesto R. Viteri, Member of the Guatemalan Government Delegation to the Peace Negotiations).

181. Lawyers Committee for Human Rights, supra note 78, at 35.

182. Id. at 36 .

183. Id. at 35-36. 
private, without prior notification. ${ }^{184} \mathrm{He}$ also has subpoena powers and the authority to commence proceedings against any violator. ${ }^{185}$

Although the ombudsman has significant legal power to investigate alleged human rights violations, many obstacles exist which interfere with his taking full advantage of this power. These obstacles include lack of support from the government ${ }^{186}$ and physical threats. ${ }^{187}$ Consequently, unless the ombudsman is strongminded and willing to risk his life, he is unlikely to get anything accomplished.

The success of the ombudsmen has been mixed. The first ombudsman, Gonzalo Menéndez de la Riva, was appointed in 1987. ${ }^{188}$ He was criticized for ineffectiveness because he did not conduct investigations quickly and did not hold violators accountable for their deeds. Menéndez de la Riva resigned on October 10, $1989 .{ }^{189}$

Ramiro de Léon Carpio, now President of Guatemala, was elected human rights ombudsman in December 1989. Human rights activists applauded his investigatory work and credited him for publicly denouncing human rights violations as no other government official in Guatemala ever had. ${ }^{190}$ In addition, de León Carpio focused on children. He took seriously the Declaration of the International Rights of the Child. ${ }^{191} \mathrm{He}$ also created the Commission of Pursuit of

184. Id.

185. Id. at $35-37$.

186. In de Léon Carpio's 1992 report, he discussed the lack of governmental support that he received and requested more. See Inter-American Commission on Human Rights, supra note 52, at 19. See also Human Rights Watch/Americas, Human Rights in Guatemala 32-33 (1994) (describing the experience of Ombudsman Jorge Mario Garcia Laguardia while trying to investigate a murder and injuries in Los Naranjales during President de Léon Carpio's first year in office).

187. See Options for United States Policy Toward Guatemala: Hearing Before the Subcomm. on Western Hemisphere Affairs of the House of Rep., 101st Cong., 2nd Sess. 59-60 (1990) [hereinafter Options] (statement of Anne Manuel, Human Rights Watch/Americas) (describing the danger Adjunct Ombudsman César Alvarez Guadamuz exposed himself to when he agreed to accompany villagers of the town of Parraxtut back to their homes after they had fled due to threats from the military for resigning from the civil patrols).

188. Id. at 37-38.

189. Id.

190. "During his term as human rights ombudsman, de León Carpio had energetically investigated and publicly denounced human rights violations, something no government official had done before in Guatemala." Human Rights Watch/Americas, supra note 186 , at 4 .

191. Lawyers Committee for Human Rights, supra note 78 , at 38. 
the Fulfillment of the Convention of the Rights of the Child, and the Commission on Prevention of Abuse of Children. ${ }^{192}$

Unfortunately, the current human rights ombudsman, Jorge Mario García Laguardia, has not been as outspoken as de León Carpio. García Laguardia has not put resources into developing the investigative wing of his office. Indeed, he informed Human Rights Watch/Americas that he does not believe his office should pursue investigations as it did when de Leon Carpio was ombudsman. ${ }^{193}$ To his credit, however, he sent a formal request to the Human Rights Commission of the Guatemalan Congress to rescind legal authority for the civil patrols. ${ }^{194}$

5. COPREDEH: Presidential Commission to Coordinate Executive Policy in Human Rights

Established by President Serrano in July 1991, COPREDEH coordinates the actions of the executive branches and guarantees communication between the judiciary and the ombudsman. ${ }^{195}$ COPREDEH is comprised of representatives of the president, the ministers of foreign affairs, the interior and the national defense, in addition to the attorney general. ${ }^{196}$ It strives to foster respect for human rights among all governmental organizations. ${ }^{197}$

Like the other governmental human rights organizations, COPREDEH is hindered by its lack of real authority. For example, Casa Alianza requested physical protection for a street educator named Axel Mejia. Mejia had received death threats for stopping thirteen members of the state security forces from beating up three street children. Although COPREDEH helped Casa Alianza to secure this protection, it was not very successful. The Ministry of the Interior approved two positions within the National Police to protect Mejia. Mejia had waited three months for the police to approve the Ministry of the Interior's request, and even then he was not secure. The two bodyguards were constantly followed by the National Police and were eventually detained. Both ended up going to trial for vaguely defined

192. Inter-American Committee on Human Rights, supra note 52, at 98.

193. Human Rights Watch/Americas, supra note 186, at 122.

194. The Civil Patrols receive their legal authority from Decree Law 19-86. It is this law that García Laguardia asked be derogated. Id. at 14.

195. Inter-American Committee on Human Rights, supra note 52, at 20.

196. Id.

197. Id. 
crimes. Casa Alianza believes that the police arranged the arrest of these two guards so that Mejia would be left unprotected and vulnerable. $^{198}$

\section{The Minors' Section of the Public Ministry}

The Minors' Section of the Public Ministry was created to protect the general welfare of children, but it lacks the resources to fulfill its responsibility. Children being represented by the Public Ministry are unlikely to have their cases pursued thoroughly and with care. As of late 1991, the Public Ministry had only five lawyers to represent the approximately five million minors in Guatemala. ${ }^{199}$

Not only does the Public Ministry lack the means to fulfill its responsibility, but it also lacks the desire. On November 3, 1991, Casa Alianza signed an agreement with the Public Ministry aimed at coordinating their efforts to help the street children of Guatemala. The agreement named the Casa Alianza Legal Aid Office as an auxiliary member of the Public Ministry, which authorized its staff to enter government centers to which they had not before had access. ${ }^{200}$ Casa Alianza did not renew the accord in 1992 because it felt that the Public Ministry was not fulfilling its obligations under the contract. ${ }^{201}$ The Public Ministry did not uphold its financial obligations, nor did it cooperate in investigations or followups on lawsuits. Instead, the Public Ministry used its agreement with Casa Alianza as a political tool when seeking foreign aid. ${ }^{202}$

\section{Reforms in the Criminal Justice System}

Historically, one of the biggest obstacles to the effective prosecution of perpetrators of human rights abuses has been a weak criminal justice system. Allegations of human rights abuses are rarely

198. Casa Alianza, 1992 Annual Report, supra note **, at 7.

199. Casa Alianza, 1991 Annual Report, supra note **, at 9; Casa Alianza, 1992 Annual Report, supra note **, at 9.

200. Interviews with Bruce Harris, Director of Casa Alianza, and Casa Alianza Legal Aid staff, in Guatemala City, Guatemala (Summer 1993).

201. Id.

202. Casa Alianza, 1992 Annual Report, supra note **, at 7-9. 
investigated and the police often lose or destroy key evidence. ${ }^{203}$ Even when the perpetrators are prosecuted, the proceedings are often dismissed or stalled by judges. ${ }^{204}$ Guatemala has recently made efforts to grapple with these problems and to strengthen the criminal justice system. ${ }^{205}$ Although the Inter-American Commission on Human Rights concluded that "there really is a greater will during this administration than in the previous one and in the jurisdictional agencies to pursue cases against government agents who violate human rights," impunity is still a serious problem. ${ }^{206}$ This is because the superiors of the perpetrators are rarely, if ever, held accountable. ${ }^{207}$

\section{a. Increasing the Number of Prosecutors}

In April 1991, new legislation that established the Office of the General Prosecutor of the Republic was introduced. ${ }^{208}$ The legislation also doubled the salary of the public prosecutor. ${ }^{209}$ The number of prosecutors increased from 58 ( 36 in the capital and 22 in the interior) to 350 , so that each city with a population over 5000 could be served. $^{210}$

203. The investigation of the murder of Guatemalan anthropologist Myrna Mack is perhaps the most infamous example of such incompetence and corruption. See InterAmerican Committee on Human Rights, supra note 52, at 22-26; see also infra notes 221-24 and accompanying text.

204. Inter-American Committee on Human Rights, supra note 52, at 26-29; Minnesota Lawyers' Report, supra note 166, at iii.

205. One of the most influential reform efforts was the Guatemala/Harvard Criminal Justice Project. From July 1987 to December 1990, a group from Harvard University Law School was in Guatemala trying to reform the Guatemalan justice system. The Project was funded by USAID and the group was working in conjunction with the Guatemalan Supreme Court. In addition to providing an extensive critique and list of suggestions for what Guatemala should do to improve its criminal justice system, the Project set up pilot courts in which the group taught judges how to conduct trials with oral arguments. Despite its successes, the Harvard group left in 1990 because of the number of human rights violations and the Project members' feeling that the Guatemalan government was doing little to address the problem. See Options, supra note 187, at 4-6, 16-19 (statement of Philip Benjamin Heymann, head of the Center for Criminal Justice, Harvard University Law School); see also id. at 34-41 (letter from Philip Benjamin Heymann).

206. Inter-American Commission on Human Rights, supra note 52, at 29.

207. Id.

208. Id. at 20.

209. Id.

210. Id. at 21. 


\section{b. A New Code of Criminal Procedure}

There have also been more radical changes. A new code of criminal procedure was brought before Congress in 1991 and became law in September 1992. It went into effect in September $1994 .^{211}$ This code does several things, including allowing oral and public trials, ${ }^{212}$ letting public prosecutors participate more in investigations, giving judges control over the imposition of penalties, and creating greater procedural guarantees and defense in trials. ${ }^{213}$

\section{c. Strengthening the Judiciary}

The new constitution strengthened the judiciary by giving it a fixed proportion of the budget. ${ }^{214}$ As of late 1992, the judiciary had a U.S. $\$ 20$ million budget expansion. ${ }^{215}$ Judicial power was increased further by requiring that judges go with the police on all investigations..$^{216}$ In addition, the number of lawyers that supervise the courts has increased from three to seventy-five, and judges are now trained specifically for criminal, juvenile, and family cases. ${ }^{217}$

A judicial studies school has also been established, ${ }^{218}$ in addition to a constitutional court which has the power to repeal any

211. See Guatemala Prospects, supra note 180, at 37 (statement of Ernesto R. Viteri, Member of the Guatemalan Government Delegation to the Peace Negotiations).

212. In their final paper, the Harvard group, see supra note 205, made several critiques and suggestions. One of the most serious problems they discussed was the lack of oral proceedings. They argued that without oral proceedings, "the judge makes a decision without ever having observed witnesses or listened to their testimony, and rarely having viewed the physical evidence." Guatemala/Harvard Criminal Justice Project, Final Report 19 (1991). Without oral arguments, public scrutiny of the judicial decision-making process is impossible; thus, corruption is more likely. See Options, supra note 187, at 11-13 (statement of Philip Benjamin Heymann, head of the Center for Criminal Justice, Harvard University Law School).

213. Inter-American Commission on Human Rights, supra note 52, at 15.

214. Lawyers Committee for Human Rights, supra note 78, at 39.

215. Inter-American Commission on Human Rights, supra note 52, at 20. It is not stated whether this budget expansion is due to the fact that the judiciary receives more from the Guatemalan government or more in international aid.

216. Lawyers Committee for Human Rights, supra note 78, at 39.

217. Inter-American Commission on Human Rights, supra note 52, at 20.

218. Id. 
executive or congressional law which it deems unconstitutional. ${ }^{219}$ Furthermore, the new constitution allows indigenous laws to be considered by courts. ${ }^{220}$

\section{d. A Critique of These Reforms}

Many problems remain, however. The threat of violence causes many judges to dismiss prominent cases that have sufficient evidence to result in conviction. ${ }^{221}$ One particularly egregious example of judges being affected by violence is the case of the Guatemalan anthropologist Myrna Mack, who was killed by Guatemalan security forces on September 11, $1990 .{ }^{222}$ Most of the twelve judges who have presided over the case have tried to resign out of fear for their lives. ${ }^{223}$ Since the principal police investigator was killed after he identified Mack's killer (a former Sergeant Major Specialist) in court, and since many witnesses have had to go into exile because of death threats, the judges have good reason to be frightened. ${ }^{224}$

In addition, cases are stalled for interminable periods of time. On August 3, 1992, Casa Alianza brought seventeen complaints against seven judges to the Supervisor of the Judicial System in an attempt to expedite the judicial process. Nevertheless, these cases still remain stagnant. $^{225}$

\section{Reforming the Police}

In Guatemala, the police are infamous for corruption and cruelty. ${ }^{226}$ The situation is so bad that many Guatemalans do not trust the police to protect their homes and businesses but instead hire private security guards. ${ }^{227}$ Although some attempts at reform have

219. Lawyers Committee for Human Rights, supra note 78, at 39. See Guat. Const. art. 268 .

220. Guat. Const. art. 268.

221. See U.S. Dep't of State, supra note 116, at 29-30.

222. Id. at 30 .

223. See Guatemala Prospects, supra note 180, at 4 (statement of Helen Mack, member of the Human Rights Office of the Archbishop of Guatemala and sister of the murdered anthropologist Myrna Mack).

224. Id.

225. Casa Alianza, 1992 Annual Report, supra note **, at 9.

226. Americas Watch, supra note 90, at 19-22; Interviews with Casa Alianza staff, in Guatemala City, Guatemala (Summer 1993); Victor Perera, supra note 97, at 165.

227. Hiring private security guards is also problematic. See infra notes $326-31$ and accompanying text. 
been made, many more steps need to be taken before the police can be trusted to uphold the law instead of violating it.

The Guatemalan police have been heavily criticized for their ineffectiveness. According to a study conducted by Florida International University, $80 \%$ of the lawyers and judges surveyed were dissatisfied with the help the police gave to the courts. ${ }^{228}$ Specifically, the police have been heavily criticized for their inadequacy in conducting investigations. ${ }^{229}$ This is particularly true when army culpability is suspected. ${ }^{230}$ Both poor training ${ }^{231}$ and a low education level ${ }^{232}$ have been cited as causes for the ineffectiveness of the police.

Corruption is also a serious problem. Fifty percent of the lawyers and judges surveyed by Florida International University indicated that police corruption was high. ${ }^{233}$ In addition, street children frequently complain that the police threaten to hurt them unless the children steal sunglasses or gold chains for them. ${ }^{234}$ According to Carlos Rafael Soto, former National Police Public Relations Director, the root of the problem is low police pay. As Soto told Americas Watch in a July 1988 interview:

They're almost all corrupt, they have to be. A cop makes Q400 (\$140) per month, but he's got a quota he has to pay to his superior once a week. In order to simply pay off his superior, he has to take bribes. Then, he has to keep his job. A police agent position sells for Q780 (\$300), but after you've been on the force for four months, you're 'fired' if you don't come up with another Q780. You either find the money-it has to be bribes, who's going to save that much on Q400 a 35.

228. Guatemala/Harvard Criminal Justice Project, Final Report, supra note 212, at

229. See Options, supra note 187, at 21-26 (statement of Philip Benjamin Heymann, head of the Center for Criminal Justice, Harvard Law School).

230. Americas Watch, supra note 90, at 21-22.

231. See Guatemala Prospects, supra note 180, at 15 (statement of Robert G. Torricelli, Chairman of the Subcomm. on Western Hemisphere Affairs of the House Comm. on Foreign Affairs).

232. As an example of this, during the Cerezo administration (1985-1990), the average education level of police officers was third grade. Harvard Criminal Justice Project, Final Report, supra note 212, at 68.

233. Id. at 35.

234. Interviews with Casa Alianza street educators and street children, in Guatemala City, Guatemala (Summer 1993). 
month?-or someone else does. ${ }^{235}$

Unfortunately, if Soto is right, corruption is destined to continue. Although a police officer's monthly salary has been raised nominally since 1988, because of inflation and the declining value of the quetzal, it is worth less. ${ }^{236}$ In 1990 , police officers made Q425 a month (less than U.S. \$100), and there was no differentiation based on merit or experience. ${ }^{237}$

Several attempts have been made to curtail the abuse and corruption of police officers. By 1988, U.S. $\$ 24.5$ million in international aid was given for police reform, including administrative restructuring, technological change, and establishing a missing persons section. In addition, national training courses were set up. ${ }^{238}$ An Office of Professional Responsibility was created by the police department, but it is not very strict. ${ }^{239}$ Furthermore, human rights are now officially included in police training, but lawyers who do the training are not themselves trained in human rights. ${ }^{240}$

Many human rights activists believe that the most effective way to end police abuses and to create police efficacy in investigating crimes is to demilitarize the police. ${ }^{241}$ For the past forty years, the chief of police has almost always been a member of the military. ${ }^{242}$ De Léon Carpio's most widely acclaimed reform as President thus far has been initiating the demilitarization of the police. ${ }^{243}$ Unfortunately, it is unclear how effective these attempts will be, since the engineers of the reform were replaced with supporters of the

235. Americas Watch, supra note 90, at 20-21.

236. Telephone interview with Rachel Garst, Washington Office on Latin America (Nov. 28, 1995) (citing Inter-American Development Bank, 1995 Report, at 308 (1995)).

237. Minnesota Lawyers' Report, supra note 166, at 24.

238. Lawyers Committee for Human Rights, supra note 78, at 30-31.

239. See Minnesota Lawyers' Report, supra note 166, at 24 (citing Gros Espiel, 1990 Report, add. 1, at 9).

240. Id. at 25.

241. See Guatemala Prospects, supra note 180 , at 16 (statement of Robert G. Torricelli, Chairman of the Subcomm. on Western Hemisphere Affairs of the House Comm. on Foreign Affairs); id. (statement of Helen Mack, member of the Human Rights Office of the Archbishop of Guatemala and sister of the murdered Guatemalan anthropologist Myrna Mack); id. at 13 (statement of Frank R. LaRue, Director, Center for Human Rights Legal Action).

242. See Guatemala Prospects, supra note 180, at 15 (statement of Ernesto Viteri, representative of the Guatemalan government delegation to the peace negotiation).

243. See Human Rights Watch/Americas, supra note 186, at 2. 
military. ${ }^{244}$

\section{Land Reform}

The National Agrarian Transfer Project was one attempt to solve Guatemala's land problems. From January 1986 to 1988, the government bought land from large private farmers and distributed it to 9612 peasants, who were to repay the government through twentyyear, interest-free loans. ${ }^{245}$ The National Agrarian Transformation Institute Deputy said in May 1989 that these policies were limited in their ability to grapple with the growing problem of rural landlessness. ${ }^{246}$

\section{Social Programs}

In 1990 , less than U.S. $\$ 2$ million, or $.4 \%$ of total public spending, was spent on social assistance and welfare. This translates into less than one quetzal per child. ${ }^{247}$ Perhaps realizing that this amount was never going to solve Guatemala's problems, President Serrano created the "Human Development, Children and Youth" policy. ${ }^{248}$

Part of this policy included a program created in 1991 to help widows and orphans of the war assimilate better into society. ${ }^{249}$ Although the president hoped that the plan would aid 25,000 widows and 12,000 orphans, by 1992 , only 894 women and their children had been reached. ${ }^{250}$

In September 1991, President Serrano created community homes to give care and education to children up to age six. ${ }^{251}$ These "care moms," as they were called, were specially trained members of the community who were given fifteen quetzals a month to care for each child. ${ }^{252}$ Serrano's goal was to have 50,000 children in households by 1996 . In 1993 , there were 1735 children in homes, about

244. Id. at 2-3.

245. See generally Lawyers Committee for Human Rights, supra note 78, at $\mathbf{4 5}$.

246. Id.

247. Inter-American Commission on Human Rights, supra note 52, at 9.

248. Id. at 9-11.

249. Id. at 96.

250. Id.

251. Id. at 95-96.

252. Id. 
$.1 \%$ of poor Guatemalan children. ${ }^{253}$

Part of this policy also included creating four juvenile centers: the first was to place and diagnose delinquents; the second was to observe street children; the third was to care for boys; and the fourth was to care for girls. ${ }^{254}$ In $1991,79 \%$ of the children sent to the state's "Juvenile Treatment and Orientation Program" (TOM) escaped and returned to the streets. ${ }^{255}$ Although Gretchen W. Mendez, a social worker for the state, asserted that the government centers had improved, there were still stories of abuse and refusals of service. ${ }^{256}$

On a more successful note, President Serrano has instituted a program in which 1.5 million children receive a school snack and school supplies. ${ }^{257}$ Furthermore, urban students may use public transportation to get to school for free. ${ }^{258}$

Serrano designed his policy to last for the years of his administration, from 1991 to $1996 .{ }^{259}$ After reading some of his plans, the Inter-American Commission on Human Rights was not impressed. They said:

The Commission finds that the resources allocated to social problems represent a portion of GNP that is disproportionate to the magnitude of the inequalities in internal distribution. Even assuming the goals proposed for the periods 1992-1996 and 1996-2000 are achieved, the social inequalities will remain and continue to be serious and discriminatory. ${ }^{260}$

\section{B. Non-governmental Attempts to Help Street Children}

Although the government has made efforts to improve the human rights situation generally, it has not focused much attention on street children in particular. Aware of the dearth of government social programs to help street children, a number of private organizations have been created to address the issue. Casa Alianza has received both

253. Id.

254. Id. at 96.

255. Casa Alianza, 1992 Annual Report, supra note **, at 13-14.

256. Interview with Gretchen W. Mendez, in Guatemala City, Guatemala (Aug. 6, 1993).

257. Inter-American Commission on Human Rights, supra note 52, at 96.

258. Id.

259. Id. at 9.

260. Id. at 12 . 
national and international acclaim for its work with street children. ${ }^{261}$ It was recently among the recipients of U.S. $\$ 3$ million from USAID set aside for a project to help street children. ${ }^{262}$ Since I spent an extended period of time working with Casa Alianza, I will describe its programs. ${ }^{263}$

\section{A Focus on Casa Alianza}

To help the children get off the streets and into more stable home settings, Casa Alianza has designed a four-step program. These steps include: the street educators, the refugios, the transition homes, and the group homes. In addition, there is a program for drug addicts and a legal aid office. From January through June 1993, there were 1378 residents in Casa Alianza programs. In June 1993 alone, there were 522 residents. ${ }^{264}$

\section{a. Stage One: The Street Educators}

The street educators provide attention and basic medical care. Presently, there are eight educators who work in Guatemala City. They go out every day except Sunday, including Saturday nights. The educators divide into groups so that they can spend concentrated time in certain areas. For safety reasons, they try to go out in male/female pairs. As often as possible, one of the two is a foreigner. This arrangement best protects the Guatemalan educators, who are then less likely to be harassed. The street educators walk every day except on Saturday nights, when they take a car.

In addition to giving basic first aid, the street educators also bring colored pencils and pictures for the children to color. When a child has injuries that require more serious medical attention, the educators take him or her to see a nurse at the boys' or girls' crisis center and, if necessary, to the hospital.

They give no food, clothing or money. As former street educator Christina McNeff explained, the children must accept the consequences

261. Id. at 97 .

262. USAID/Guatemala, Central American Programs Highlights (1995) (on file with author).

263. The information in the section on Casa Alianza is from Casa Alianza's statistics (on file with author), or from interviews with Casa Alianza staff, in Guatemala City, Guatemala (Summer 1993).

264. Casa Alianza statistics (July 1993) (on file with author). 
of their decision to live on the street. They know that if they want food or clothing, they can get it at either the boys' or girls' crisis center.

The educators also take the street children out for three or four activities a month. They might take them swimming or to a farm to play soccer. The only rule is that the children cannot be under the influence of drugs or have any drugs in their possession. The goal of these activities is three-fold: first, Casa Alianza wants the children to stop using drugs; second, it wants the children to engage in athletics since they get little recreation time on the street, and third, it wants the children to enter Casa Alianza. Street educator Wellington Tello estimates that one or two children enter the crisis center after each activity.

The street educators' job is a difficult one. They seek to gain the trust of the children in hopes of convincing them to leave the streets and enter Casa Alianza. Gaining a person's trust is always a challenging task, but when a child has been abused by parents and the police, it becomes even harder. In addition, the street educators keep daily records of who they see. This allows Casa Alianza to estimate the number of street children in Guatemala City. Finally, the educators often are the first people to discover when street children have been abused by the police or others.

\section{b. Stage Two: The Refugios}

There are refugios, or crisis centers, for both girls and boys. They admit children at any time of the day or night, as long as they do not smell like drugs or have any in their possession. This restriction exists because most of the children in the refugios have drug problems, and Casa Alianza does not want them to be further tempted. The refugios offer shelter, food, and clothing to children who have just left the streets. In an attempt to help children make the transition from life on the street to life in a home, the refugios provide activities, require the children to do some chores, and offer counseling.

After President Serrano's attempt to seize dictatorial powers in May 1993 by dissolving the Supreme Court and Congress, suspending constitutional rights, and arresting the human rights ombudsman, ${ }^{265}$ many children came off the streets and into the refugios. No one knew

265. For a more detailed discussion of President Serrano's bid for absolute power, see Human Rights Watch/Americas, supra note 186, at 126-29. 
what was going to happen, and they went to the refugios for protection. ${ }^{26}$

c. Stage Three: The Transition Homes

Children who stay continuously in the refugios for three months are ready to move on to the hogares de transition, or transition homes. Since children have different needs, this rule is not unyielding. Some children may enter the transition homes much earlier. The transition homes are smaller and more stable then the refugios. There are two transition homes, one for boys (twenty-person capacity) and one for girls (fifteen-person capacity).

\section{d. Stage Four: The Group Homes}

The final step in the process is the group home. There are fifteen group homes in Antigua, the former capital of Guatemala, and ten in Guatemala City, with approximately fifteen children per home. In addition, there is a home in Nebaj, a city in the highlands of the Quiche region. The other inhabitants of these homes become the children's families. The children live there until they turn eighteen, and all of them study and work.

\section{e. Drug Rehabilitation Programs}

Drug addiction is one of the most serious problems street children have. Since there are no government programs dealing with drug addiction, Casa Alianza has designed programs for the most seriously addicted. Boys with severe drug problems can go to Nujuyu, a drug rehabilitation program, instead of the refugio.

Nujuyu is located in Magdalena Milpas Altas between Guatemala City and Antigua. It sits on a huge plot of land, which allows the children to pick fruit and play outdoor games. As with all of Casa Alianza's programs, the children are free to leave at any time, but it helps that they are removed from the temptations of Guatemala City.

At Nujuyu, the children receive more individual attention than in the other programs. There are five educators for a maximum of

266. Interview with Carlos Toledo, Casa Alianza staff, in Guatemala City, Guatemala (July 13, 1993). 
twenty-five residents in Nujuyu, and children see a psychologist for both group and private sessions once a week. According to Program Director Oscar Toledo, Nujuyu has about a $35 \%$ success rate in getting children through the program drug-free. ${ }^{267}$

Once the children have been there for three months, they are usually ready to move on to Alamos, a transition home for drug addicts. At Alamos, there are two educators, and as in regular transition homes, children can begin going to school and working. About $70 \%$ of the children who enter Alamos make it through the three-month program drug-free. When the children are ready, they move to group homes. At this point, they become integrated with the children who went through the non-drug-crisis route.

\section{f. A Program Designed Specifically to Help Young Mothers}

Although fewer girls live on the streets than boys, girls' unique needs also must be met. ${ }^{268}$ In addition to its other facilities devoted exclusively to girls, Casa Alianza has created a special program to help street girls who are also mothers or who are pregnant. The program seeks to detoxify young mothers and to teach them to be responsible for themselves and their children. Niña/Madre offers girls extensive counseling and tries to rebuild the girls' self-esteem. Although it tries to reintegrate the girls into their families, it does not force girls to leave after a certain period of time. Niña/Madre is equipped to handle about sixteen mothers and their children.

\section{g. Auxiliary Program: The Legal Aid Office}

In addition to its homes, Casa Alianza has a legal aid office. It helps all the children, whether on the street or in a program, to get identification papers and to make formal complaints if they are mistreated. It conducts investigations and puts pressure on the Public Ministry and the judicial system to take the complaints seriously. It also helps Casa Alianza workers who have been threatened.

267. Interview with Oscar Toledo, Casa Alianza staff, in Guatemala City, Guatemala (July 1993).

268. An article in Siglo Veintuno from July 24, 1993, estimated that about $33 \%$ of the street children are girls. See El Drama de los Niños, supra note 15. 


\section{h. Family Reintegration Program ${ }^{269}$}

The Family Reintegration Program strives to accomplish an extremely difficult task-reintegrating street children into their families. In the late fall of 1993, USAID gave Casa Alianza funding to implement the program, and in January 1994, the program began. Since that time, the program has achieved remarkable success. As of June 1995, 169 children had been reintegrated into their families.

Reintegration demands much time and energy. To begin, Casa Alianza staff must choose a suitable candidate for reintegration. Once a child is selected from the Casa Alianza programs, intensive counseling occurs separately with the child and the family. Staff members look for the reasons the child left initially and do their best to address these problems. Only when the child and family are ready will the child return home.

Even then, Casa Alianza still maintains contact. Case workers make frequent visits, and both the child and the parents continue counseling. Parenting classes are also available and encouraged.

Taking into account the considerable time and expense, ${ }^{270}$ it is impressive that Casa Alianza has succeeded in reintegrating 169 children. At this point, however, no attrition statistics have been compiled. As Beth Hogan of USAID in Guatemala pointed out, even with intensive counseling, many of the problems underlying the behavior of runaways may be insolvable. Some children simply prefer the freedom of life on the street, despite the hardship and regardless of whether their home situations have improved. ${ }^{271}$

\section{A Critique of Casa Alianza}

Despite Casa Alianza's successes, it also has some serious problems. The biggest problem is underfunding. Since there are only about eight street educators at any time, Casa Alianza can cover only

269. Information about this program comes from a telephone interview with Rachel Garst, Washington Office on Latin America (Nov. 17, 1995).

270. USAID allotted Casa Alianza $\$ 136,000$ over three years. This amount of money was supposed to cover both the Family Reintegration Program and a training program, including manuals, for Casa Alianza staff. Rachel Garst of the Washington Office on Latin America was extremely impressed by how well Casa Alianza was using its money. Id.

271. Id. 
three of Guatemala City's twenty-one zones. ${ }^{272}$ The zones are large, and each street educator pair can only visit a handful of the locations that street children frequent. More street educators would allow Casa Alianza to go into more neighborhoods and to reach out to more children.

The legal aid office is also in need of more funding. ${ }^{273}$ Although the legal aid office offers competent legal help to street children, it is understaffed. There is only one fully-certified lawyer, and although there are four law students who do much of the work, one lawyer is simply not enough to meet the demands of 5000 street children. ${ }^{274}$

More crisis centers are also needed. The Casa Alianza crisis center for boys is large and crowded and located in the middle of Guatemala City. Although the centers may be good for the first few nights, the temptations of the street become too much for some of the children and they leave. Casa Alianza needs additional crisis centers in rural areas, with a lot of space, so that the children can play. The preference many children have for a rural setting is exemplified by the fact that some street children say they will go to Nuhuyu but not to the crisis center. The biggest differences between the two are size (Nuhuyu cares for fewer children and gives them more individualized attention) and location (Nuhuyu is in the countryside and has a lot of land for the children to play on).

Not only does Casa Alianza need more crisis centers, but it also needs a facility that will make it easier for children to make the transition from street life to the refugio. At present, street educators can only offer street children basic first aid, pictures to color, and comfort. Although these are important, they are not enough. For a child to satisfy any more of her needs through Casa Alianza, she must make the enormous step of giving up drugs. Before she can even enter

272. Interviews with Casa Alianza street educators and staff, in Guatemala City, Guatemala (Summer 1993).

273. Id.

274. In Guatemala, getting a law degree takes about seven years after high school. Students must do four years of course work and then do a practica, during which time they do actual legal work. They then take an examination and then write a thesis. All of the law students who work in the Legal Aid Office are working on their practica. Interview with Marvin Rabanales, Casa Alianza Staff, in Guatemala City, Guatemala (July 1993). Licenciado Rudi de Leon was the only lawyer working for Casa Alianza in the summer of 1993. Gustavo Rodolfo de Leon Rodas has since replaced him. As of November 1994, there were four law students working for Casa Alianza. 
the crisis center, her breath must not smell like glue, which requires that she has not inhaled glue for several hours. For the majority of children, this is simply too big a step to take. Instead, Casa Alianza would be wise to design an in-between step that would give children the support necessary to make this transition. For example, Casa Alianza could have a separate crisis center where children could go for the time it requires to rid their breath of the smell of glue.

In addition to these problems, some believe that Casa Alianza suffers from an unforgivable structural problem: it provides long-term residential care. ${ }^{275}$ In these experts' opinions, homes offering a substitute family are problematic for several reasons. First, they make children dependent on charity, thus promoting passivity both among residents and among those who hope to become residents. Second, homes like Casa Alianza offer a lifestyle that children cannot maintain once they leave, thus creating unrealistic expectations that can lead to bitterness. ${ }^{276}$ Instead, these critics suggest that non-residential, community-based organizations be set up. These are aimed at encouraging children to learn marketable skills while remaining in their communities and not breaking ties to their families. ${ }^{277}$

Although this criticism has some merit when applied to children who maintain ties to family members, it is less applicable when applied to children who are abandoned or who are unwilling to return home. Many of the children I met at Casa Alianza were either orphans or had suffered such extreme abuse at home that they had no desire to return. For those children, a substitute family is extremely important.

More importantly, Casa Alianza's recently created Family Reintegration Program ${ }^{278}$ represents a concerted effort to restore children to their communities. By attempting to grapple with the underlying problems that drive children to flee their homes, Casa Alianza makes it easier for children to return home. In addition, intensive therapy for both parents and children increases the likelihood that the reintegration process will succeed. Although the reintegration of 169 children represents a significant success, it is still small in comparison with the number of street children in Guatemala

275. See Agnelli, supra note 4, at 75-76.

276. Id.

277. Id.

278. See supra notes 269-71 and accompanying text. 
City. ${ }^{279}$ Casa Alianza needs more funding like that given by USAID in order to expand this valuable program to help more children and families.

\section{International Efforts to Help Street Children}

In 1993, USAID funded the four-year, $\$ 3$ million Street Children Support Project. ${ }^{280}$ The Project's general goal is three-fold: to improve the human rights situation of children by raising public awareness, to enhance the environment in which policy regarding children's rights is formulated, and to strengthen the ability of private volunteer organizations to provide services to needy children. ${ }^{281}$ The Project aims to help children who live on the street, who work on the street, or who have been abused. ${ }^{282}$

Philosophically, the Project is based on the belief that, regardless of what measures are taken, a population of children will always live on the street. ${ }^{283}$ In addition, the Project acts on the principle that the greatest success will be achieved by trying to lower the number of children who opt to live on the street and by giving them services that satisfy their basic needs and protect their rights once they are on the street. ${ }^{284}$

In practical terms, the Project differs from many other service providers. Instead of devoting all its resources to offering basic necessities to those already living on the street while trying to get them to leave the street, the Project grapples with the deeper problems that drive children onto the street or cause them to be abused in the first place. ${ }^{285}$

To accomplish these goals, USAID gave money to Casa Alianza, ${ }^{286}$ PAMI, ${ }^{287}$ and the Office of the Human Rights

279. See supra notes 10-14 and accompanying text.

280. USAID, USAID/Guatemala - Central American Programs: Highlights (1995).

281. USAID, Guatemala Project Paper: Street Children Support Project 3 (June 22, 1993).

282. Id.

283. Id.

284. Id.

285. Id.

286. For a description of Casa Alianza's programs, see supra notes 263-78 and accompanying text.

287. PAMI is a local non-governmental organization. PAMI stands for Proyecto de Ayuda Maternale. Telephone interview with Beth Hogan, USAID/Guatemala (Nov. 17, 1995). 
Ombudsman. ${ }^{288}$ As described above, Casa Alianza has used its money to create the Family Reintegration Program, which, thus far, has achieved remarkable success. ${ }^{289}$ In addition, Casa Alianza has used the money to strengthen its staff training program. ${ }^{290}$

PAMI used USAID's money to channel resources into grassroots organizations. ${ }^{291}$ More importantly, PAMI has helped local NGOs in project planning and design. ${ }^{292}$ When USAID first envisioned the Project, it thought that local NGOs would simply write grants requesting money. USAID found that, apart from Casa Alianza, most NGOs were not very adept at formulating proposals. ${ }^{293}$ In the eighteen months since the Project started, PAMI has done an exceptionally good job at helping local NGOs with project planning and design. ${ }^{294}$ Among the programs that PAMI has helped to develop are outreach programs, micro-enterprise development programs, and a sex education program for girl prostitutes, which uses peer counselors who are identified as leaders and then given proper training. ${ }^{295}$

Finally, the Project gave money to the Office of the Human Rights Ombudsman. ${ }^{296}$ The money was intended for several purposes: to work on the Codigo de Menores (Code for the Protection of Children's Rights), to fund a national education campaign about children's rights, to provide training to the ombudsman's staff members, and to fund a hotline service that would allow the Ombudsman's Office to receive complaints about human rights violations against street children. ${ }^{297}$ Although work has begun on these plans, the Ombudsman's Office has suffered from planning problems similar to those suffered by the local NGOs. ${ }^{298}$ To address this problem, USAID gave PAMI authority to help the Ombudsman's Office with its project design and implementation. ${ }^{299}$

In the eighteen months since the Project began, it has been

288. For a description of the responsibilities of the ombudsman, see supra notes 180-187 and accompanying text.

289. See supra notes $268-70$ and accompanying text.

290. Interview with Beth Hogan, supra note 287.

291. Id.

292. Id.

293. Id.

294. Id.

295. Id.

296. Id.

297. Id.

298. Id. See supra note 293 and accompanying text.

299. See interview with Beth Hogan, supra note 287. 
successful. The high number of children who have been reunited with their families through Casa Alianza's Family Reintegration Program and the interesting array of programs that PAMI has helped to organize are indicative of this success. With over a year left in the Project, much more is likely to be accomplished.

\section{ALternatives: NeW APPROACHES to PROBLEM-SOLVING}

Although past attempts to help street children have achieved some success, more can and should be done. If American policy-makers are serious about changing the situation for street children in Guatemala, they should pursue both short- and long-term goals. First, they should focus on helping children leave the streets by giving money to direct service providers that have proved successful in the past. Second, they should work on ending abuses against street children. Finally, they should take measures to stop future generations of Guatemalans from becoming street children.

\section{A. Helping Children to Leave the Streets}

Direct service providers like Casa Alianza are the best way to help street children change their lives. They have the most immediate, everyday contact with the children. Not only should existing organizations be better funded, but alternative models, especially ones that have proved successful elsewhere, should be tried. ${ }^{300}$

The overwhelming opinion of those who work with street children, both in the United States and in Central America, is that street education is extremely important. ${ }^{301}$ This means teaching kids wherever they might be: in markets, under bridges, and in parks and streets. They must be taught about health issues such as AIDS and also must be given practical skills such as literacy and numeracy.

300. For additional information about the following programs and the countries in which they are located, see Appendices B and C, infra.

301. In a telephone interview, Marilyn Rocky, Regional Director of Childhope-USA, emphasized that programs were changing their focus from institutionalizing street children to working with them in their own environment. The institutionalization model, Rocky argued, has two fundamental flaws. The first is that it takes care of children until they reach a certain age but then lets them go completely. Because these children have never learned to deal with their own environment, it is unclear whether they will be able to do so as adults. Second, institutionalization is incapable of handling the swelling number of street children. Telephone interview with Marilyn Rocky (June 21, 1994). 
Vocational training is also important. ${ }^{302}$ Former street child Carlos Palacios suggested that children be invited to participate in workshops that teach easily learnable skills that give quick feedback, such as carpentry, electricity, music and ceramics. ${ }^{303}$

Programs to help children rejoin their families should also be designed. This requires counseling before the children and the family reunite, and it also requires advice concerning programs available to families to help reduce the stress of poverty. Casa Alianza's Family Reintegration Program ${ }^{304}$ is an excellent example of such a program, but more efforts along these lines are needed.

Finally, more drug treatment programs are needed. At present, there is only one free drug treatment program in Guatemala, that of Casa Alianza. It would be valuable to have a drug crisis center located in Guatemala City where children could get counseling without having to commit to full treatment. Since many are not ready or willing to make the commitment to a full-time program like Casa Alianza's Nuhuyu, a walk-in clinic would be an effective intermediate step.

The programs described in the following sections might be considered as models for Guatemala.

\section{Center for the Defense of the Child (CDM)}

The CDM is located in Belém, a Brazilian city of about 1.5 million people..$^{305}$ Its staff of professionals offers children social, psychological and legal support. ${ }^{306}$ What is most noteworthy about the CDM is its stress on building self-esteem. ${ }^{307}$

The CDM has developed a variety of ways to improve selfesteem. One technique is to have children answer questions like, "Who am I?" and "What makes me an individual, different from everyone else, unique and a valuable part of society? ${ }^{\text {308 }}$ The CDM has also designed an array of activities. For example, staff members make a

302. Street Children, supra note 1, at 88 (testimony of Marilyn Rocky, Regional Director, Childhope-USA).

303. Id. at 60 (statement of Carlos Palacios, former street child and employee of Childhope).

304. See supra notes $269-71$ and accompanying text.

305. Tom Scanlon et al., Working with Street Children, 3 Development in Practice, No. 1 (Feb. 1993).

306. Id.

307. Id.

308. Id. 
collage of photographs of different people. Then they ask the children to pick out those they like most and least and explain why. The goal is to build a sense of self through negative and positive identification with others. ${ }^{309}$

The philosophy behind the program makes sense. If the children think of themselves as worthless, then they are unlikely to change, either by keeping clean or by leaving the streets altogether. The CDM stresses self-esteem as an important building block to change and self-growth, and it would be wise for other programs to take this seriously.

\section{Neutral Ground}

Neutral Ground is a twenty-four-hour center in Kansas City, Kansas that seeks to reunite runaway youths between the ages of ten and seventeen with their families. ${ }^{310}$ As soon as a child arrives, she is assigned a primary counselor who will follow her case to the end. The counselor tries first to find out why the child ran away. If the problem is not sexual or physical abuse, then within twenty-four hours the counselor contacts the parents. She explains the program at Neutral Ground, assures the parent that the child is safe, discusses the expectations of the program, gives a brief description of the major problems the child is having, and then seeks the permission of the parent for the child to stay and the commitment of the parent to work with Neutral Ground. ${ }^{311}$

At this point, counseling begins. If a reconciliation is made, then the child goes home. She will be visited at least five times in the course of the next year to see how she is doing. If no reconciliation is made and the child does not want to return home, then Neutral Ground begins investigating other possible living arrangements. ${ }^{312}$

3. The Bridge

The Bridge offers two major kinds of outreach to the children

309. Id.

310. Street Kids-Homeless and Runaway Youth: Hearings Before the Subcomm. on Children, Family, Drugs and Alcoholism of the Senate Comm. on Labor and Human Resources, 101st Cong., 2nd Sess. 101-822 (1990) (statement of Clarence Small, Director of Emergency Services for Wyandotte House, Inc., a comprehensive youth organization).

311. Id.

312. Id. 
of Boston, Massachusetts: streetwork and a medical van. ${ }^{313}$ Outreach workers go out twice a day to locations where street children hang out. They let the children know about Bridge programs in addition to referring them to counselors who can talk to them about their problems. ${ }^{314}$ The organization has specialized counselors for drug abuse. ${ }^{315}$ It also has a medical van that drives around offering free medical care. The kids can have a sandwich and a cup of cocoa if they want, and there is always someone who will listen..$^{316}$

The strength of the Bridge is that it supports the child while he is leaving the street, instead of making support conditional on having left the street. Not all children have the willpower to leave the temptations of the street for a more stable environment. The Bridge recognizes this and is willing to help children in their chosen environment instead of first making them move to a new environment that the children view as potentially dangerous. ${ }^{317}$ This willingness to work with children where they feel most comfortable is particularly important for children who have a hard time establishing trust.

\section{Boscoñia/La Florida}

Boscoñia/La Florida in Bogotá, Colombia is a project that has achieved remarkable success in helping street children. ${ }^{318}$ It succeeds for three major reasons. First, it allows children to take responsibility for other children. Second, like Casa Alianza, it lets children progress at their own pace through different steps from being non- to fullyresidential. Finally, it teaches the children skills that will help them get jobs when they leave Boscoñia. Designed by a Catholic priest, Father James de Nicolo, Boscoñia/La Florida works through five steps. $^{319}$

The first step is recruiting children. Older children, who are one step higher in the process, go out to areas frequented by street Inc.).

313. Id. at 6 (statement of Virginia Price, M.Ed., Clinical Director of the Bridge,

314. Id.

315. Id.

316. Id.

317. Id.

318. Development: What Works: Hearing Before the International Task Forces of the House Select Comm. on Hunger, 101st Cong., 1st Sess. 101-04. (1989) (statement of Deborah Szekely, President, Inter-American Foundation).

319. Id. 
children and offer them warm drinks or some other treat. Their goal is only to make friends and offer the children someone to talk with if they so desire. Recruiters also invite the children to a place where they can bathe, clean their wounds, wash their clothes, eat a light meal, and play. The facilities are kept sparse so that the children do not become dependent. While the street children eat breakfast, the older children tell them about the benefits of making it through the process to the last step, which they describe as a beautiful campus called La Florida. The children who are most interested in making it through the process are invited to spend the night in a simple dormitory. The purpose of this stage is to introduce the child to the program and to encourage him to change without removing him completely from his normal life. ${ }^{320}$

If the children are interested, then they can go to step two. At step two, the children receive some basic education, essentially just to identify how much they know, and then do basic chores. They can leave at any time, but if they leave before a month is over, they cannot come back for six months. ${ }^{321}$

Once they have been at step two for a month, they move to step three, where they go to school. There are two volunteer nurse superintendents, and the new participants are taught by older children in the program. The children in the program stay until they learn to read and write, which takes anywhere from one to four years. ${ }^{322}$

Step four is a sort of junior high school where the children learn geography and history. Here, there is a garden where they grow enough vegetables for the other facilities. ${ }^{323}$

The final step is a vocational school called La Florida, where the children learn a variety of practical skills, including welding, construction, and automobile repair. The children make money doing this work; the money helps support the rest of the Boscoñia system. The children are paid in special Bosconia currency that is printed by the Bank of Colombia. Although they cannot use it, they deposit it in the Boscoñia bank and exchange it for real money when they leave. They use this money to buy clothing at the Boscoñia store. ${ }^{324}$

320. Id.

321. Id.

322. Id.

323. Id.

324. Id. 


\section{B. Reducing Abuses Against Street Children}

The United States can play an instrumental role in reducing the number of abuses against street children. To begin, American policy-makers should state openly to the Guatemalan government and to the international community that they are concerned about the number of abuses against street children. ${ }^{325}$ They should then create a fact-finding commission that will go to Guatemala to find out who is responsible for the abuses against street children and why the abuses occur. To accomplish this task, members of the commission should talk with many people, including international human rights experts, representatives of Guatemalan human rights groups and children's advocacy groups, the Catholic Church, and the Guatemalan government and military. The commission should try to get abuse statistics from more than one source. Once policy makers have determined who is committing the violations against street children, they should respond accordingly.

\section{Private Security Forces}

Private security forces have been accused of hurting street children. ${ }^{326}$ Because a general sentiment exists in Guatemala that the police are corrupt or incompetent, ${ }^{327}$ many people take personal responsibility for defending their homes or businesses. They hire armed guards who are members of the police, army, or private security organizations. $^{328}$ These individuals are extremely difficult to prosecute.

Getting the evidence for a crime committed by a member of a private security organization is difficult. Many private police services are not registered, which makes it difficult to find the responsible

325. It is important that this statement be public for several reasons. First, such a public statement will acknowledge and support the work that local human rights groups are doing to help street children. Such acknowledgment is important to protect members of these groups from reprisals by abusers of street children. Second, speaking publicly will put pressure on the Guatemalan government to lower the number of abuses against street children. Finally, Guatemala will be put on notice that if it does not take actions to lower the number of abuses, the United States may take actions against it.

326. See Casa Alianza, 1992 Annual Report, supra note **, at 2-4, 10; Casa Alianza, 1991 Annual Report, supra note **, at 4-7.

327. See supra notes $226-44$ and accompanying text.

328. Interview with Bruce Harris, supra note 161. 
party. ${ }^{329}$ Furthermore, many services simply transfer the guard who committed the crime. After the murder of the street child Francisco Chacon Torres by a private security guard, the head of the security firm transferred the killer. ${ }^{330}$

When the guard is a member of the police or the military, he might as well be unregistered. Neither the government nor the business that hired the guard wants to take responsibility for the guard's actions. On July 13, 1993, the Minister of Defense told Bruce Harris, the Director of Casa Alianza, that he would no longer allow members of the Guatemalan police or armed forces to serve as private security guards. ${ }^{331}$

If the commission finds that private security forces are responsible for abuses against street children, then the U.S. government should urge the Guatemalan government to prosecute these individuals to the full extent of the law. If the commission discovers that members of the police or army are committing these abuses as paid security guards, then the U.S. government should pressure Guatemala to live up to its promise to Bruce Harris.

\section{The Police or Army}

There have been many documented attacks by members of the police or army against street children. The question that must be asked, however, is whether these attacks are by individual members of the police or army who acting on their own initiative, or whether the attacks are actually being encouraged by high officials in the police or army.

a. How the U.S. Should Respond If the Attacks Are Made by Individual Policemen and Soldiers, but They Are Not Being Encouraged by Those in Control

If the attacks are made by individuals, then U.S. policy-makers should state openly that the U.S. considers the rights of street children worth protecting and that it is the responsibility of the army and the

329. Id.

330. Interview with Casa Alianza Legal Aid Office staff, in Guatemala City, Guatemala (June 8, 1993).

331. Id. See also Interview with Bruce Harris, supra note 161. 
police to make sure that abuses, particularly by members of their own organizations, do not occur. Policy-makers should stress that state security forces should train the police and troops so that they do not commit abuses. If the Guatemalan police and military do not take the above-stated measures, Congress should decrease, and eventually cut, funding aimed at the Guatemalan police and military. ${ }^{332}$

At present, U.S. funding of the Guatemalan military has been severely reduced due to human rights violations. ${ }^{333}$ This reduction is an appropriate sanction. It is important, however, that funding not be resumed until human rights violations against street children are reduced.

b. How the U.S. Should Respond If the Police and Army Are Actively Encouraging Violations

Clearly, it is extremely serious if the upper echelon of the Guatemalan security forces are encouraging abuses against street children. If this is the case, U.S. policy-makers should state publicly that they are disturbed by the open disregard for the rights of street children by the Guatemalan security forces, and for this reason, they will cut aid to the police and/or military (depending on who is encouraging the abuses) until it becomes evident that the official policy is no longer to hurt street children but instead to protect them. ${ }^{334}$

\section{Immunity}

Regardless of who is committing the violations, at present it is unlikely that they will be prosecuted and then sentenced for their crimes. To ensure that violators actually suffer the consequences of

332. If the U.S. does decide to cut military and police aid, it should follow through on its decision completely. In the past, the U.S. has suspended military aid but continued to have military operations in Guatemala. See Guatemala Prospects, supra note 180, at 13 (statement of Frank R. LaRue, Director, Center for Human Rights Legal Action).

333. Telephone interview with Anne Manuel, Americas Watch (Nov. 20, 1995). See also Appendix D.

334. Cutting aid to the military because of human rights abuses is not a new idea. See Options, supra note 187, at 77 (statement of Frank R. LaRue, Senior Fellow, Commission on U.S. Latin American Relations, former labor leader in Guatemala, and Director, Center for Human Rights Legal Action); id. at 49 (statement of Anne Manuel, Human Rights Watch/Americas). On July 24, 1990, the U.S. government cut military aid to Guatemala due to excessive human rights abuses. Id. at 131-35 (Appendix 2, H. R. Con. Res. 355). 
their actions, U.S. policy-makers should state publicly that they are concerned by the lack of convictions of those who violate the human rights of children. In addition, they should take a number of the following actions.

\section{a. Consulting an Expert for Investigations}

Guatemala should be encouraged to invite an independent expert to observe and to participate in its investigatory procedures for several reasons. First, it is possible that the Guatemalan police are not qualified to conduct a thorough investigation. ${ }^{335}$ If that is the case, then the Guatemalan police and prosecutor could learn a great deal from working with an expert in investigatory procedures. This knowledge would be helpful both in the particular case and in the future. In addition, in his capacity as observer, the expert could report to both the Guatemalan and the international community whether the investigation was thorough and fair. Such reports could help to restore the credibility of the investigations in Guatemala. ${ }^{336}$

\section{b. Observing Trials}

Making sure that independent observers witness trials of alleged abusers of street children would make the procedure more fair. Judges, lawyers, witnesses, and police officers knowing that they are being observed, would be more likely to follow the law. Furthermore, an observer could make a public statement concerning the proceedings of the trial. She could state whether she thinks the proceedings were fair or unjust.

If public attention and scrutiny are ineffective in making trials more fair, U.S. policy-makers should decide whether there is anything else they should do, either to help make the Guatemalan judicial system work better or to penalize the system for working badly.

335. See supra notes $228-32$ and accompanying text.

336. For a detailed discussion of this policy suggestion see Options, supra note 187, at 21-22 (statement of Philip Benjamin Heymann, head of the Center for Criminal Justice, Harvard Law School). 


\section{c. Changing Legal Representation Rules}

One change that would make it more likely for abusers of street children to be prosecuted to the full extent of the law would be to change the legal representation rules. Article 14 of the Codigo de Menores (Code of Laws Governing Minors) states that only a child's legal guardian can be his or her legal representative. ${ }^{337}$ If a minor has no legal guardian, then the state takes over this role. This means that no private lawyer or legal aid office, like that of Casa Alianza, can take the child's case. ${ }^{338}$

Since the Public Ministry has neither the manpower nor the will to represent everyone who needs it, ${ }^{339}$ children will not get the same level of attention they would receive from private organizations. Instead, the law should be changed to allow private individuals or organizations to represent children if the child's family requests it. Alternatively, a judge should be given the discretion to decide if it would be in the best interest of the child to be represented by the organization.

\section{d. Changing the Witness Rules}

Another reform that would make it easier to prosecute those who violate the rights of street children would be to change the witness rules. Article $\mathbf{4 3 5}$ of the Guatemalan Constitution forbids anyone under the age of sixteen from being a witness in court. ${ }^{340}$ Since most crimes against street children happen at night when few people are around, it is hard to find witnesses who will testify. Either they are adults who do not want to get involved, or they are children who, because of their age, do not have a legal voice. This law creates a huge barrier against the successful prosecution of abusers.

Instead, the law should be changed to allow children of any age to offer testimony in court. Although the finder of fact should determine whether the child is telling the truth, age should not prevent a child from testifying.

337. Interview with Marvin Rabanales, supra note 274.

338. Id.

339. See supra notes 199-202 and accompanying text.

340. Interview with Marvin Rabanales, supra note 274. 


\section{Stopping Children from Becoming Street Children}

Ending the phenomenon of street children in Guatemala is a daunting task. Since street children are a manifestation of glaring societal problems in Guatemala, it would be a mistake for the U.S. to think that money and political pressure are all that is required. Helping Guatemala to grapple with these problems will take much patience and political courage. American politicians must know which kinds of reform are reasonable to ask the Guatemalan government to make, and which are not.

In addition, Americans must be willing to exert some political pressure to get these reforms enacted. Such pressure might be in the form of public statements emphasizing the importance of these reforms to the Guatemalan government and to the international community. Alternatively, the State Department could discuss the progress of these reforms in an annual report.

If none of these measures worked, the U.S. could pressure the Guatemalan government in less traditional ways, such as by restricting travel for pleasure to the U.S. At present, many people who fly back and forth to Guatemala are in the upper classes. Since these same individuals may also be the political, economic and military leaders in Guatemala, they may respond if something they care about, like travel, is threatened

Finally, if none of this is successful, the U.S. could consider reducing aid to Guatemala. According to Section 701 of the International Financial Institutions Act, the U.S. should consider human rights relevant in determining whether to grant loans to Guatemala through the International Development Bank, the World Bank, and the International Monetary Fund. ${ }^{341}$

The Guatemalan government should be encouraged to enact the following reforms. The reforms I suggest are rather low cost, yet they are likely to have immediate effects on the lives of street children.

1. Educational Reform

Although illiteracy stems, for the most part, from the fact that many families cannot afford to send their children to school instead of having them work, for those who do go to school, educational

341. See Guatemala Prospects, supra note 180, at 57 (statement of Frank R. LaRue, Director, Center for Human Rights Legal Action). 
opportunities are often bleak. It is not uncommon to see all the children in a village crammed into two classrooms, with almost no separation for age or ability. ${ }^{342}$ Larger and better equipped schools are necessary, especially in rural areas.

In addition, the school day needs to be designed to fit the needs of students. Children who work in the fields with their parents are less likely to attend school if it meets during the morning rather than during the late afternoon or evening. Similarly, urban schools must be specially designed to meet the needs of working street children. UNICEF, Childhope, and the National Commission for Action for Children have designed a program in Guatemala that is geared specifically toward street children, offering a more flexible schedule and skills workshops. ${ }^{343}$

Since low skill level is part of the reason children end up on the street (i.e., low skills = low paying jobs = poverty $=$ increased chance of family disintegration), it is important that children are better educated, so that they will be better equipped as adults to earn a decent living. This requires not just teaching traditional academic subjects but also offering occupational workshops. ${ }^{344}$

\section{Daycare}

Daycare facilities would also help in preventing children from going to the streets. Since many parents are forced due to economic hardship to work long hours, daycare would give the children a place to go instead of being left at home alone. In particular, if the daycare centers could provide a hot meal and some educational activities, the children would not be induced to go out into the streets in search of food or entertainment. ${ }^{345}$

\section{New Drug Laws}

In addition, serious consideration must be devoted to legal

342. When I went to Nebaj to visit Casa Alianza's homes there in the summer of 1993, I stopped by a local school. I was told by Casa Alianza staff that the extreme overcrowding I witnessed there was common.

343. Street Children, supra note 1, at 51 (statement of Per Engebak, American Representative, UNICEF).

344. The UNICEF Project described above stressed occupational workshops and income generating activities. Id.

345. See Agnelli, supra note 4, at 90. 
changes for drug addicts. Casa Alianza has been on the forefront of this thinking. In the past, addicts were sent to jail. ${ }^{346}$ Now the Guatemalan government may send them to drug rehabilitation programs. $^{347}$

In addition, pressure should be put on glue-manufacturing companies to produce a product that is less intoxicating. The Minnesota-based company H.B. Fuller has known for a long time that thousands of children throughout Central America are addicted to its glue Resistol, but it has done little to alleviate this situation. ${ }^{348}$ Finally, after extensive pressure, Fuller announced in the summer of 1992 that it would stop the sale and production of its adhesive products where evidence existed that they were being abused. In response, Fuller received corporate citizenship awards and laudatory newspaper editorials. ${ }^{349}$

Despite this announcement, Fuller withdrew its products only from Guatemalan and Honduran distributorships but continued to sell to industrial users in these countries. It hoped that various distribution controls would stop secondary sales to children. According to Guatemalan Congressman Raphael Barrios, Fuller failed to affect abuse of Resistol by children. He stated that street children are still sniffing Resistol and it is available everywhere. ${ }^{350}$

Many of those who criticize Fuller advocate not withdrawal from the market but instead using an additive that would make

346. Interview with Marvin Rabanales, supra note 274.

347. Id.

348. In addition, the Coalition on Resistoleros, a group which criticizes Fuller's sale of Resistol, claims that it bought in Costa Rica paint manufactured by Fuller that contained lead levels 50 times higher then what would be allowed in the U.S. See Susan E. Peterson, H.B. Fuller Bids Goodbye to Patriarch, Star Tribune, Apr. 22, 1994, at 14; see also Diana B. Henriques, Black Market for a "Good Citizen": Critics Say Fuller Isn't Doing Enough to Curb Glue-Sniffing, N.Y. Times, Nov. 26, 1995, at F1, F11.

349. See Minnesota Company Continues Glue Sales in Latin America (National Public Radio broadcast, Apr. 22, 1994) (hereinafter National Public Radio] (transcript available in LEXIS, Nexis Library); Kids' Glue-sniffing Raises Accountability Questions; Critics Demand U.S. Firm Stop Producing Solvent-based Substances in Latin America, Dallas Morning News, June 13, 1993, at 73-74; Peterson, supra note 348, at 14.

350. See National Public Radio, supra note 349; see Susan E. Peterson, Segment of Tonight's 'Dateline NBC' Has More Bad News on Glue Made by the H.B. Fuller Co., TV Show: Resistol Still Being Abused by Latin American Kids, Star Tribune, Sept. 28, 1993, at D1. 
inhalation uncomfortable. ${ }^{351}$ Following this philosophy, the Casa Alianza Legal Aid Office proposed a new drug law in 1992 that mandates that factories add mustard seed oil to glue and paint thinner. The mustard will induce vomiting and make inhalation extremely uncomfortable. ${ }^{352}$

Although such a law could radically affect the use of inhalants by street children, it is insufficient. Children sniff glue because they are cold, hungry, and unhappy. ${ }^{353}$ Unless their real needs are addressed, children will fill their emptiness with something else, be it paint thinner, gasoline, or other substances.

\section{CONCLUSION}

Although the situation of street children in Guatemala is bleak, it is not without hope. National and international attention is starting to focus on resolving the problem, and the situation is improving. Attacks against street children have decreased and programs are now available for those who want to leave the street.

Yet policy-makers must stop and consider what they strive to achieve. If the goal is to get this generation of children off the street, then policy-makers need only to increase the amount of aid given to youth in crisis programs and diversify the programs available. If policy makers want to break the cycle of despair for future generations, however, they have a much more challenging task. Lasting change requires deep structural reform of Guatemalan society as a whole.

351. This is the approach that the Tester company of Illinois took. When Tester learned that many children were getting high from its airplane glue, it added mustard seed oil, which curbed inhalation by making it extremely uncomfortable. See National Public Radio, supra note 349 , at 67.

352. Interview with Marvin Rabanales, supra note 274. For more information about the law, see Analizarán Ley de Protección al Menor, Prensa Libre, July 10, 1993.

353. See supra notes $38-41$ and accompanying text. 


\section{APPENDIX A \\ GENERAL INFORMATION ABOUT GUATEMALA ${ }^{354}$}

\section{Poverty}

1. $94.4 \%$ of unemployed Guatemalans live in extreme poverty (1989 statistics).

2. $66.8 \%$ of employed Guatemalans live in extreme poverty (1989 statistics).

3. $60 \%$ of the population lives in rural areas, and of these, $83 \%$ do not have enough money to pay for basic necessities (1990 statistics).

4. $80 \%$ of the entire population is living in poverty.

5. Poverty increased from $63 \%$ in 1980 to $77 \%$ in 1989.

II. Health

1. Health programs cover $14 \%$ of the population (1992 statistics).

2. $33.5 \%$ of the population suffers from malnutrition, of these, $57.8 \%$ has chronic malnutrition (1987 statistics).

3 . $37 \%$ of children between the ages of five and nine suffer from malnutrition.

4. Infant mortality is at $6 \%{ }^{355}$

5. Child mortality for those five and under was 102 per 1000 live births in 1989. The principal causes of death were diarrhea, respiratory infections, and malnutrition.

6. 15,000 cases of cholera were reported in 1992 .

III. Housing

1. $50 \%$ of the population lacks minimal quarters.

2. $62 \%$ of the population has only dirt floors.

3. More than $50 \%$ of families have only one room for the entire family.

4. $63 \%$ of the population does not have latrines.

354. Unless otherwise noted, statistics are from Inter-American Commission on Human Rights, supra note 52.

355. United Nations Development Programme, supra note 63, at table 28 (Health and Nutrition), at 292. 
IV. Land

1. $2.1 \%$ of farm owners have $72 \%$ of the farmland and earn $90 \%$ of the farm credit.

2. 548,000 small farm owners have an average of 2.6 acres.

3. Every year, Guatemala loses 153,000 hectares of forest.

\section{Education}

1. Spending on education was $1.8 \%$ of GDP (1985 statistics, with recent estimates showing no significant change).

2. Illiteracy for individuals aged fifteen and older is $45 \%$ (1990 statistics).

3. 63 of every 100 children who began school in $1978 \mathrm{had}$ dropped out by 1984 .

4. In rural areas, $49 \%$ of girls enroll in school and most drop out.

VI. Unemployment

Unemployment rose from $31.2 \%$ in 1980 to $41 \%$ in 1990 .

VII. Child Labor

$1,600,000$ children are working to support themselves and their families.

VIII. War

1. There are 150,000 orphans.

2. There are 50,000 widows.

IX. Social Spending

In 1990 , spending on social assistance and welfare programs equaled U.S. $\$ 2$ million, or $.4 \%$ of the budget. This comes out to less than one quetzal per child per year. 


\section{APPENDIX B \\ COMPARISON OF PRIVATE ORGaNIZATIONS}

\begin{tabular}{|c|c|c|c|c|}
\hline $\begin{array}{l}\text { Name of } \\
\text { Program }\end{array}$ & $\begin{array}{l}\text { City \& } \\
\text { Country of } \\
\text { Origin }\end{array}$ & $\begin{array}{l}\text { General } \\
\text { Information } \\
\text { re: Street } \\
\text { Children }\end{array}$ & $\begin{array}{l}\text { Strengths of } \\
\text { Programs }\end{array}$ & $\begin{array}{l}\text { Potential for } \\
\text { Use in } \\
\text { Guatemala }\end{array}$ \\
\hline $\begin{array}{l}\text { Casa } \\
\text { Alianza }\end{array}$ & $\begin{array}{l}\text { Guatemala } \\
\text { City, } \\
\text { Guatemala }\end{array}$ & $\begin{array}{l}\text { 1. } 5000 \text { in } \\
\text { Guatemala } \\
\text { City. }{ }^{366} \\
\text { 2. Glue } \\
\text { commonly } \\
\text { used. } \\
\text { 3. Abuse by } \\
\text { state forces } \\
\text { and private } \\
\text { citizens. }\end{array}$ & $\begin{array}{l}\text { 1. Street } \\
\text { educators. } \\
\text { 2. Specialized } \\
\text { programs for } \\
\text { drug addicts } \\
\text { \& young } \\
\text { mothers. } \\
\text { 3. Legal aid } \\
\text { office. }\end{array}$ & $\begin{array}{l}\text { Effective } \\
\text { advocate \& } \\
\text { supporter of } \\
\text { street } \\
\text { children for } \\
\text { over } 10 \\
\text { years. }\end{array}$ \\
\hline $\begin{array}{l}\text { Center for } \\
\text { the Defense } \\
\text { of the Child } \\
\text { (CDM) }\end{array}$ & $\begin{array}{l}\text { Belém, } \\
\text { Brazil }\end{array}$ & $\begin{array}{l}\text { 1. } 200,000 \\
\text { estimated in } \\
\text { Brazil. }^{357} \\
2.4611 \text { killed } \\
\text { between } \\
1988-1990.368\end{array}$ & $\begin{array}{l}\text { 1. Stress on } \\
\text { self-esteem. }\end{array}$ & Very feasible. \\
\hline $\begin{array}{l}\text { Neutral } \\
\text { Ground }\end{array}$ & $\begin{array}{l}\text { Kansas } \\
\text { City, KS, } \\
\text { U.S.A. }\end{array}$ & $\begin{array}{l}1.1-1.3 \\
\text { million } \\
\text { runaways per } \\
\text { year } \\
\text { nationally. } 359\end{array}$ & $\begin{array}{l}\text { 1. Stress on } \\
\text { reunification } \\
\text { with family. } \\
2 . \text { Use of } \\
\text { counseling. }\end{array}$ & $\begin{array}{l}\text { 1. Lack of } \\
\text { phones would } \\
\text { make contact } \\
\text { between } \\
\text { center \& } \\
\text { families } \\
\text { difficult. } \\
\text { 2. Costly. } \\
\text { 3. May be } \\
\text { feasible. }\end{array}$ \\
\hline
\end{tabular}

356. Street Children, supra note 1, at 53-54.

357. Dead End Kids, Newsweek, May 25, 1992, at 16.

358. This number is based on Brazilian federal police reports. Amnesty International, Report: Brazil: Extrajudicial Execution of Street Children in Sergipe 2 (July 1992).

359. National Network of Runaway and Youth Services, Runaway and Homeless Fact Sheet 1 (n.d.). 


\begin{tabular}{||l|l|l|l|l||}
\hline The Bridge & $\begin{array}{l}\text { Boston, } \\
\text { MA, U.S.A. }\end{array}$ & See above. & $\begin{array}{l}\text { 1. Outreach } \\
\text { workers. } \\
\text { 2. Drug abuse } \\
\text { counseling. } \\
\text { 3. Lots of } \\
\text { work on the } \\
\text { streets. }\end{array}$ & $\begin{array}{l}\text { 1. Cost an } \\
\text { issue, but } \\
\text { feasible. }\end{array}$ \\
\hline $\begin{array}{l}\text { Gamines } \\
\text { Project }\end{array}$ & $\begin{array}{l}\text { Bogotá, } \\
\text { Colombia }\end{array}$ & $\begin{array}{l}\text { Estimates } \\
\text { range from } \\
\text { 5000 total in } \\
\text { Colombia } \\
\text { to } 12,000 \text { in } \\
\text { Bogotá } \\
\text { alone. }\end{array}$ & $\begin{array}{l}\text { 361 } \\
\text { given } \\
\text { responsibility } \\
\text { in } \\
\text { maintaining } \\
\text { the program. } \\
\text { 2. Stress on } \\
\text { education \& } \\
\text { practical } \\
\text { skills }\end{array}$ & Very feasible. \\
\hline
\end{tabular}

360. Gary Barker et al., Attitudes and Knowledge of AIDS and Sexually Transmitted Diseases among Street Youth in Bogotá Colombia: Findings from Recent Focus Group Discussions 3 (n.d.) (Childhope-USA Working Paper No. 5) (quoting UNICEF (1990)).

361. Id. (quoting J. Harrison, Muchachos de la Calle (Gamines): Special Focus: Drug Addiction (1987)). 
APPENDIX C

COMPARISON OF QUALITY OF LIFE

\begin{tabular}{|c|c|c|c|c|c|c|}
\hline Country & Pop..$^{362}$ & $\begin{array}{l}\text { Aug. } \\
\text { Ann. } \\
\text { Pop. } \\
\text { Growth } \\
1991- \\
2000^{363}\end{array}$ & $\begin{array}{l}\text { Life } \\
\text { Expec- } \\
\text { tancy } \\
\text { at } \\
\text { Birth }^{364}\end{array}$ & $\begin{array}{l}\text { Malnu- } \\
\text { trition } \\
\text { Under } \\
\text { Age } \\
5^{365}\end{array}$ & $\begin{array}{l}\text { \% Share } \\
\text { of } \\
\text { Income } \\
\text { or } \\
\text { Consum- } \\
\text { ption } \\
(1989){ }^{366} \\
1 . \\
\text { Bottom } \\
20 \% \text {. } \\
2 . \text { Top } \\
20 \% \text {. }\end{array}$ & $\begin{array}{l}\text { Urbani- } \\
\text { zation. }{ }^{367} 1 \\
\text { \% of } \\
\text { Tot. Pop. } \\
\text { 2. Avg. } \\
\text { Ann. } \\
\text { Growth } \\
\text { Rate } \\
1980 . \\
1991 .\end{array}$ \\
\hline $\begin{array}{l}\text { Guate- } \\
\text { mala }\end{array}$ & $9.5 \mathrm{M}$ & $2.9 \%$ & 64 & $34 \%$ & $\begin{array}{l}\text { 1. } 2.1 \% \\
\text { 2. } 63.3 \%\end{array}$ & $\begin{array}{l}\text { 1. } 40 \% \\
\text { 2. } 35 \%\end{array}$ \\
\hline Brazil & $9 \mathrm{M}$ & $1.4 \%$ & 66 & $13 \%$ & $\begin{array}{l}\text { 1. } 2.1 \% \\
2.67 .5 \% \\
(1989)\end{array}$ & $\begin{array}{l}\text { 1. } 76 \% \\
\text { 2. } 3.3 \%\end{array}$ \\
\hline USA & $253 \mathrm{M}$ & $.9 \%$ & 76 & $11 \%$ & $\begin{array}{l}1.4 .7 \% \\
2.41 .9 \% \\
(1985)\end{array}$ & $\begin{array}{l}\text { 1. } 75 \% \\
\text { 2. } 1.1 \%\end{array}$ \\
\hline $\begin{array}{l}\text { Colom- } \\
\text { bia }\end{array}$ & $33 \mathrm{M}$ & $1.5 \%$ & 69 & $12 \%$ & $\begin{array}{l}1.4 .0 \% \\
2.53 \% \\
(1988)\end{array}$ & $\begin{array}{l}\text { 1. } 71 \% \\
\text { 2. } 2.9 \%\end{array}$ \\
\hline
\end{tabular}

362. Population. "M" symbolizes "million." United Nations Development Programme, supra note 63, table 26 (Population Growth and Projections), at 288-89.

363. Id.

364. Id. table 1, at 238-39.

365. Id. table 28 , at 292-93.

366. Id. table 30 , at $296-97$.

367. Id. table 31, at 298-99. 


\author{
APPENDIX D \\ U.S. SECURITY ASSISTANCE AND \\ APPROVED WEAPONS SALES TO GUATEMALA ${ }^{368}$
}

\begin{tabular}{||l|l|l|l||}
\hline $\begin{array}{l}\text { Security } \\
\text { Assistance }\end{array}$ & 1994 & 1995 & 1996 \\
\hline $\begin{array}{l}\text { Economic Support } \\
\text { Fund (ESF) }\end{array}$ & $\$ 300,000$ & $\begin{array}{l}\$ 2 \text { million } \\
\text { (estimated) }\end{array}$ & 0 requested \\
\hline $\begin{array}{l}\text { International } \\
\text { Military Education \& } \\
\text { Training (IMET) }\end{array}$ & $\$ 36,000$ & $\begin{array}{l}\$ 2 \text { million } \\
\text { (estimated); } \\
\text { suspended } \\
\text { on } \\
3 / 12 / 95^{371}\end{array}$ & $\begin{array}{l}\$ 250,000 \\
\text { requested }\end{array}$ \\
\hline $\begin{array}{l}\text { International } \\
\text { Narcotics Control } \\
\text { INC) }^{373}\end{array}$ & $\$ 2$ million & $\$ 2.5$ million & $\begin{array}{l}\$ 2.55 \text { million } \\
\text { requested }\end{array}$ \\
\hline
\end{tabular}

\begin{tabular}{||l|l|l|l||}
\hline Weapons Sales $^{374}$ & 1994 & 1995 & 1996 \\
\hline Commercial Arms Sales & NA & $\$ 1.5$ million & $\begin{array}{l}\$ 796,000 \\
\text { requested }\end{array}$ \\
\hline Foreign Military Sales & 0 & 0 & $0^{376}$ \\
\hline
\end{tabular}

368. Unless otherwise noted, all of the information for this table comes from U.S. Dep't of State, Congressional Presentation for Foreign Operations, Fiscal Year 1995 (1995).

369. Id. at 405.

370. ESF is considered security assistance because it is cash and, therefore, fungible. Telephone interview with Anne Manuel, Human Rights Watch/Americas (Nov. 20,1995 ).

371. Id.

372. Even though, technically, IMET is still suspended, the money is available pending progress on human rights cases. Id.

373. This funding goes to the Treasury Police, and other organizations. Id.

374. U.S. Dep't of State, supra note 368, at 489.

375. $\$ 8$ million was recorded in State Department statistics, but, according to Anne Manuel, this is a mistake. Manuel had spoken with a State Department staff member who said the true amount of approved sales was zero. Telephone interview with Anne Manuel, supra note 370 . 